DOI: 10.33188 /vetheder. 891760

Derleme / Review

\title{
Türkiye su ürünleri sektöründe mevcut durum, sorunlar ve çözüm önerileri
}

\author{
İsmail ŞAKIMA ${ }^{1, a^{*}, \text { Mustafa Bahadır ÇEVRIMLI' }} \dot{I}^{2, b}$ \\ ${ }^{I}$ Tarlm ve Orman Bakanlığ Balıkçıllk ve Su Ürünleri Genel Müdürlüğ̈̈, Ankara, Türkiye \\ ${ }^{2}$ Selçuk Üniversitesi Veteriner Fakültesi Hayvan Sağliği Ekonomisi ve İşletmeciliği Anabilim Dall, Konya, Türkiye \\ ORCID: 0000-0002-6404-805X ${ }^{a} ; 0000-0001-5888-242 \mathrm{X}^{b}$
}

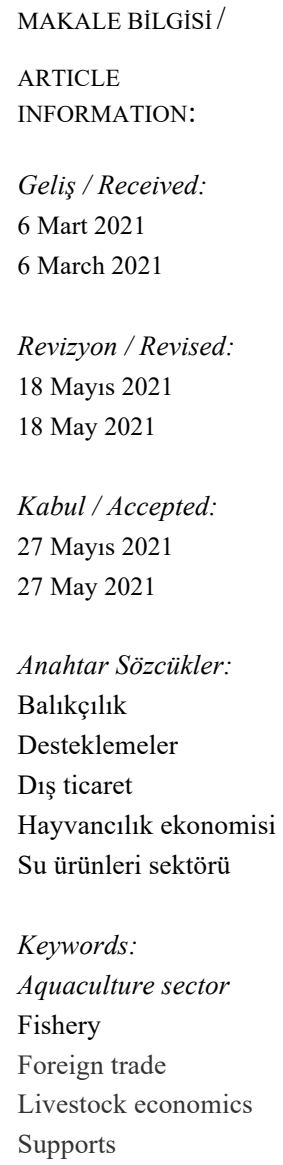

ÖZET:

Dünya nüfusundaki hızlı artış, yükselen yaşam standartları ve tüketim alışkanlıklarındaki değişiklikler, balık ve diğer balıkçılık ve su ürünleri yetiştiriciliği ürünlerine olan talebi her geçen gün artırmaktadır. Türkiye ve dünyadaki balıkçılık ve su ürünleri sektörü, hayvancılık sektörünün sürekli gelişen, ülkelere ihracat geliri ve gıda güvenliğine katkı sağlayan önemli bir alt üretim dalıdır. Bu çalışmada su alanı bakımından zengin coğrafi yapıya sahip olan Türkiye'nin balıkçılık ve su ürünleri sektörünün mevcut durumu değerlendirilmiş ve dünyadaki mevcut durumla karşılaştırılmıştır. Türkiye'nin balıkçılık ve su ürünleri yetiştiriciliği sektöründe yükselen ivmeyi sürdürerek dış ticarette rekabet gücünün artırılması gerekmektedir. bunun için üretim planlaması, katma değerli ürünlerin üretilmesi, balık stoklarının sürdürülebilir olarak yönetilmesi ve verimlilik artışı hedeflenmelidir. Türkiye'de balıkçılık ve su ürünleri sektöründe araştırma ve geliştirme faaliyetleri desteklenerek, hammaddede olan dışa bağımlılı̆̆ını azaltabilecektir. Sektör gelişimi açısından gündemde tutulması gereken diğer konular arasında uluslararası standartları karşılayan yeni işleme tesislerinin kurulması ve mevcut tesislerde maksimum verim sağlanması yer almaktadır.

\section{The Current Situation, Problems and Solutions in Turkey's fisheries and aquaculture sector}

ABSTRACT:

The rapid increases in world population, rising standards of living and changes in consumption habits increase demands for fish and other fisheries and aquaculture products every day. The fisheries and aquaculture sector in Turkey and the world is an important sub-production branch of the livestock sector that continuously develops, providing export income to countries and contributing to food security. In this study, it is evaluated the current situation of Turkey's fisheries and aquaculture sector that have rich water areas in terms of geographical structure and compared it to the current situation in the world. Competitiveness in foreign trade needs to be increased by maintaining a rising momentum in Turkey's fisheries and aquaculture sector. For this, production planning, production of value added products, sustainable management of fish stocks and increase in productivity should be targeted. By supporting research and development activities in the fisheries and aquaculture sector in Turkey, this can able to reduce foreign dependency on raw materials. Other issues that should be kept on the agenda in terms of sector development include establishing new processing facilities that meet international standards and ensuring maximum efficiency in existing facilities. 


\section{Giriş}

Hayvansal gıdalar insanların beslenmesinde önemli protein kaynaklarının başında gelmektedir. Hayvansal kökenli gıdalar içerisinde balık, besin değeri ve özellikle proteinin oranının yüksek olması bakımından önemli bir yeri olduğu söylenebilir. Balık etinin protein değeri \%18-20 civarındadır. Balık yağı diğer yağlara göre en fazla omega-3 yağ asidinin bulunduğu kaynaktır (22). Sağlıklı ve doğru beslenmenin önemini bilen uluslar, protein kaynaklarını zenginleştirmek ve çeşitlendirmek maksadıyla hayvansal kökenli ürünlerin üretimine daha fazla uğraş vermektedirler. Besin öğeleri içerisinde kıymetli bir gıda olan su ürünlerinin işlenmesi, depolanması ve pazarlanmasında yüksek standartların yakalanması ve korunması gelişmiş ülkelerde olduğu gibi ülkemizde de öncelikler arasına girmiştir (5). Balık stoklarında farklı sebeplerden dolayı meydana gelen azalma, denizlerde ve iç sularda akuatik kaynakların doğru ve etkin değerlendirilmesi yönünde yeni zorunlulukları ortaya çıkarmıştır. Bu sebepten su ürünleri yetiştiriciliği, hâlihazırda hayvancıllı̆ın diğer alt sektörlerine göre yüksek ivmeyle büyümeye devam etmektedir (4). Su ürünleri sektörü, hayvancılık sektörü içerisinde; başta gıda olmak üzere sağlık, çevre, turizm, imalat ve lojistik sektörleri ile yakın ilişkileri nedeniyle iktisadi ve sosyal kalkınma açısından son derece önem arz eden bir konumdadır (11). Su ürünleri yetiştiriciliği yalnızca beslenmede değil, istihdam yaratması, birçok ülke için döviz girdisi, kırsal kalkınmadaki rolünün artması ve yoksullukla mücadelede ucuz hayvansal protein temini açısından da önemli rol oynamaktadır (22). Bu durumu teyit eden "2018 Dünyada Balıkçılık ve Su Ürünleri Yetiştiriciliğinin Durumu” başlığıyla yayınlanan FAO raporunda; "balıkçılık ve su ürünleri yetiştiriciliğinin milyonlarca insanın, gıda, beslenme ve istihdamı açısından hayati önem taşıdığı, sektörün ekonomik kalkınmaya ve yoksullukla mücadeleye karşı yaptığı katkının arttığı” (14) ifade edilmiştir.

\section{Dünya Su ürünleri Sektöründe Mevcut Durum}

Su ürünleri yetiştiriciliği dünyada hızla gelişmekte ve tüm gıda sektörü içerisinde önemi gittikçe artmaktadır. Avcılık yolu ile elde edilen avlanabilir ürün miktarı sınırlı olduğundan, aşırı avcılık nedeniyle ilerleyen yıllarda avcılık stoklarında azalmaya neden olur. Dünyada su ürünleri üretiminin yüzde 37'si yetiştiricilik yoluyla elde edilmektedir. Uzun vadede yetiştiricilik sektörünün üretim bakımından avcılık sektörünü geçmesi beklenmektedir. Dünya su ürünleri üretimi Tablo-1'de incelendiğinde avcılık yoluyla elde edilen su ürünleri miktarı değişken seyir gösterirken, yetiştiricilik yoluyla elde edilen üretimin yıllar içinde artış gösterdiği görülmektedir $(4,16)$.

Tablo 1: Dünya su ürünleri üretimi (ton)

Table 1: World fisheries and aquaculture production (metric tons)

\begin{tabular}{cccccccc}
\hline \multirow{2}{*}{ Yıllar } & \multicolumn{3}{c}{ Avcılık (Ton) } & \multicolumn{3}{c}{ Yetiştiricilik (Ton) } & Toplam(Ton) \\
\cline { 2 - 7 } & Deniz & İçsu & Toplam & Deniz & İçsu & Toplam & \\
\hline 2010 & 76.278 .358 & 10.863 .861 & 87.142 .219 & 21.861 .535 & 35.945 .661 & 57.807 .196 & 144.949 .415 \\
2011 & 81.136 .060 & 10.502 .636 & 91.638 .969 & 22.737 .131 & 37.105 .127 & 59.842 .258 & 151.480 .954 \\
2012 & 77.767 .502 & 10.881 .090 & 88.648 .592 & 23.925 .870 & 39.576 .434 & 63.502 .304 & 152.150 .896 \\
2013 & 78.832 .286 & 10.915 .515 & 89.747 .801 & 24.855 .137 & 42.130 .065 & 66.985 .202 & 156.733 .003 \\
2014 & 79.349 .911 & 11.045 .110 & 90.395 .021 & 26.225 .099 & 44.329 .027 & 70.554 .126 & 160.949 .147 \\
2015 & 80.521 .369 & 11.149 .469 & 91.670 .838 & 27.039 .998 & 45.772 .262 & 72.812 .260 & 164.483 .098 \\
2016 & 78.285 .821 & 11.365 .442 & 89.651 .263 & 28.578 .979 & 47.978 .996 & 76.557 .975 & 166.209 .238 \\
2017 & 81.222 .361 & 11.908 .155 & 93.130 .516 & 30.055 .941 & 49.554 .288 & 79.610 .229 & 172.740 .745 \\
2018 & 84.421 .966 & 12.021 .387 & 96.443 .353 & 30.782 .285 & 51.339 .568 & 82.121 .853 & 178.565 .206 \\
\hline
\end{tabular}

Kaynak: BSGM 2020

Not: Üretim rakamlarına su bitkileri ve deniz memelileri dahil değildir.

FAO verilerine göre dünyada bulunan yaklaşık 11 milyon yetiştiricilik işletmesinde (5 milyon adedi Çin'de) 360 tür üretilmektedir. Bu 360 türün 25 adedinin ticari değeri bulunmaktadır. 
Tablo 2: Dünya su ürünleri yetiştiriciliği bölgesel dağılımı

Table 2: World aquaculture regional distribution

\begin{tabular}{lccccccccc}
\hline Kitalar/Mil.Ton & $\mathbf{2 0 0 1}$ & $\mathbf{2 0 0 5}$ & $\mathbf{2 0 1 0}$ & $\mathbf{2 0 1 1}$ & $\mathbf{2 0 1 2}$ & $\mathbf{2 0 1 3}$ & $\mathbf{2 0 1 4}$ & $\mathbf{2 0 1 5}$ & Pay(\%) \\
\hline Asya Kitas1 & 30,3 & 39,2 & 52,5 & 54,8 & 59,0 & 62,6 & 65,5 & 68,3 & 89,1 \\
Amerika Kitas1 & 1,7 & 2,2 & 2,6 & 2,8 & 3,0 & 3,1 & 3,3 & 3,2 & 4,4 \\
Avrupa Kitas1 & 2,1 & 2,1 & 2,5 & 2,7 & 2,9 & 2,8 & 2,9 & 2,9 & 4,0 \\
Afrika Kitas1 & 0,4 & 0,6 & 1,3 & 1,4 & 1,5 & 1,6 & 1,7 & 1,7 & 2,2 \\
Okyanusya Kitas1 & 0,1 & 0,2 & 0,2 & 0,2 & 0,2 & 0,2 & 0,2 & 0,2 & 0,3 \\
\hline Toplam & 34,6 & 44,3 & 59,1 & 61,9 & 66,5 & 70,2 & 73,6 & 76,5 & 100 \\
\hline
\end{tabular}

Kaynak: FAO 2016

Yine, FAO verilerine göre Tablo 2'de de görülebileceği gibi, Asya kıtasındaki ülkeler dünyadaki su ürünleri yetiştiriciliğinin \%89,1'ni karşılamaktadır $(13,22)$.

Tablo 3: Bazı ülkelerin su ürünleri üretimi (2018)

Table 3: Fisheries and aquaculture productions of some countries (2018)

\begin{tabular}{|c|c|c|c|c|c|c|c|}
\hline \multirow[t]{2}{*}{ Ülkeler } & \multicolumn{3}{|c|}{ Avcilık(Ton) } & \multicolumn{3}{|c|}{ Yetiştiricilik(Ton) } & \multirow{2}{*}{$\begin{array}{l}\text { Toplam } \\
\text { (Ton) }\end{array}$} \\
\hline & Deniz & İçsu & Toplam & Deniz & İçsu & Toplam & \\
\hline $\mathrm{ABD}$ & 4.722 .132 & 22.437 & 4.744 .569 & 203.687 & 264.498 & 468.185 & 5.212 .754 \\
\hline AB Toplamı & 5.307 .684 & 105.062 & 5.412 .746 & 1.085 .242 & 279.175 & 1.364 .417 & 6.777 .163 \\
\hline Bangladeş & 654.687 & 1.216 .538 & 1.871 .225 & 214.583 & 2.190 .833 & 2.405 .416 & 4.276 .641 \\
\hline Brezilya & 489.382 & 224.910 & 714.292 & 76.530 & 528.470 & 605.000 & 1.319 .292 \\
\hline Çin & 12.684 .012 & 1.963 .808 & 14.647 .820 & 17.968 .335 & 29.591 .445 & 47.559 .780 & 62.207 .600 \\
\hline Ekvador & 598.684 & 123 & 598.807 & 510.360 & 29.390 & 539.750 & 1.138 .557 \\
\hline Endonezya & 6.707 .545 & 508.712 & 7.216 .257 & 1.905 .703 & 3.546 .103 & 5.451 .806 & 12.668 .063 \\
\hline Fas & 1.356 .219 & 15.502 & 1.371 .721 & 477 & 660 & 1.1137 & 1.372 .858 \\
\hline Filipinler & 1.889 .188 & 162.973 & 2.052 .161 & 503.461 & 322.599 & 826.060 & 2.878 .221 \\
\hline Hindistan & 3.620 .145 & 1.700 .108 & 5.320 .253 & 805.300 & 6.260 .700 & 7.066 .000 & 12.386 .253 \\
\hline İran & 723.248 & 105.624 & 828.872 & 69.759 & 369.959 & 439.718 & 1.268 .590 \\
\hline Japonya & 3.103 .902 & 27.023 & 3.130 .925 & 612.821 & 30.054 & 642.875 & 3.773 .800 \\
\hline Kanada & 784.603 & 43.124 & 827.727 & 181.149 & 10.174 & 191.323 & 1.019 .050 \\
\hline G.Kore & 1.330 .351 & 5.755 & 1.336 .286 & 539.345 & 29.005 & 568.350 & 1.904 .636 \\
\hline Malezya & 1.455 .612 & 6.089 & 1.461 .701 & 116.124 & 101.770 & 217.894 & 1.679 .595 \\
\hline Meksika & 1.468 .915 & 223.625 & 1.692 .540 & 176.995 & 70.197 & 247.192 & 1.939 .732 \\
\hline Misir & 104.696 & 268.590 & 373.286 & 265.979 & 1.295 .478 & 1.561 .457 & 1.934 .743 \\
\hline Myanmar & 1.144 .00 & 889.110 & 2.033 .110 & 23.458 & 1.106 .892 & 1.130 .350 & 3.163 .460 \\
\hline Nijerya & 485.967 & 392.188 & 878.155 & 90 & 291.233 & 291.323 & 1.169 .478 \\
\hline Norveç & 2.488 .670 & 309 & 2.488 .979 & 1.354 .813 & 129 & 1.354 .942 & 3.843 .921 \\
\hline Peru & 7.150 .352 & 19.465 & 7.169 .817 & 42.199 & 61.398 & 103.597 & 7.273 .414 \\
\hline Rusya & 4.839 .916 & 268.942 & 5.108 .858 & 30.373 & 169.132 & 199.505 & 5.308 .363 \\
\hline Şili & 2.122 .431 & 0 & 2.122 .431 & 1.265 .180 & 874 & 1.266 .054 & 3.388 .485 \\
\hline Tayland & 1.510 .936 & 196.200 & 1.707 .136 & 478.580 & 412.284 & 890.864 & 2.598 .000 \\
\hline Tayvan & 811.177 & 3.737 & 814.914 & 164.181 & 119.020 & 283.201 & 1.098 .115 \\
\hline Türkiye & 283.955 & 30.139 & 314.094 & 209.370 & 105.167 & 314.537 & 628.631 \\
\hline Vietnam & 3.190 .749 & 156.290 & 3.347 .039 & 1.346 .150 & 2.787 .850 & 4.134 .000 & 7.481 .039 \\
\hline
\end{tabular}

Kaynak: BSGM 2020

Ülkeler bazında su ürünleri üretimi incelendiğinde ise Tablo 3'de bariz bir şekilde gösterildiği gibi Çin, dünyanın en büyük su ürünleri üreticisi konumundadır. 


\section{Üretim:}

Su ürünleri sektöründe üretim, avcılık ve yetiştiricilik yoluyla gerçekleşmektedir. Avcılık yoluyla balıkçılık, en eski uğraşlardan biri olup, günümüzde de Dünya'da ve Türkiye'de sosyo-ekonomik açıdan önemini korumaktadır. Son yüzyılda gelişen teknoloji, artan nüfus ve hayvansal proteine olan talep su ürünleri kaynakları üzerinde olan baskının artmasına neden olmuştur. Su ürünleri kaynaklarının yenilenebilir olmasına rağmen sonsuz olmadığı gerçeği sonucu ile karşı karşıya kalınmıştır $(2,23)$. Su ürünleri kaynaklarının etkin ve verimli kullanımı ve yönetimi konusunda tüm dünyada sorunlar yaşanmaktadır. Bu sorunların bir bölümünü idari denetim ve kontrol sorunları oluştururken, diğer bir kısmını ise balıkçı filosunun etkin ve verimli yönetilememesinden kaynaklanan sorunlar oluşturmaktadır. Birçok ülkede balıkçı filosunun artışı ve teknolojik kapasitesinin yükselişi, sınırlı canlı kaynağın paylaşımında ve su ürünleri gelirlerinde de problemlere yol açmaktadır. Su ürünleri otoriteleri, kaynakların etkin ve verimli kullanıldığı takdirde sürdürülebilir üretimin mümkün olduğunu ifade etmektedir $(9,23)$. Su ürünleri yetiştiriciliği ise tüm dünya da istikrarlı büyüme hızıyla devam eden bir sektördür. FAO tarafından tüm gıda sektörleri içerisinde hızlı gelişen ve sürekli büyüyen bir sektör olarak lanse edilmektedir (14). Tablo 4'de gösterildiği gibi 2010 yılında tüm dünya genelinde 57,8 milyon ton gerçekleşen yetiştiricilik üretimi, 2018 y1lında 82,1 milyon tona ulaşmıştır (23).

Tablo 4: Dünya'da su ürünleri avcıllk ve yetiştiricilik üretimi (Milyon Ton)

Table 4: Fisheries and aquaculture production in the world (Million metric tons)

\begin{tabular}{cccccccccc}
\hline & $\mathbf{2 0 1 0}$ & $\mathbf{2 0 1 1}$ & $\mathbf{2 0 1 2}$ & $\mathbf{2 0 1 3}$ & $\mathbf{2 0 1 4}$ & $\mathbf{2 0 1 5}$ & $\mathbf{2 0 1 6}$ & $\mathbf{2 0 1 7}$ & $\mathbf{2 0 1 8}$ \\
\hline Avcılık & 87,1 & 91,6 & 88,6 & 89,7 & 90,4 & 91,7 & 89,7 & 93,1 & 96,4 \\
Yetiştiricilik & 57,8 & 59,8 & 63,5 & 67,0 & 70,6 & 72,8 & 76,6 & 79,6 & 82,1 \\
Toplam & 144,9 & 151,5 & 152,2 & 156,7 & 160,9 & 164,5 & 166,2 & 172,7 & 178,6 \\
\hline
\end{tabular}

Kaynak: BSGM 2020

2010 ile 2018 yıllarını yetiştiricilik açısından kıyasladığımızda \%42,04'lük bir artış oranın gerçekleştiği, avcılık üretiminde ise \%10,67'lik artış oranının gerçekleştiği görülmektedir. Toplam üretim açısından bakacak olursak, 2010 ile 2018 yılındaki değişimin \%23,25'lik artış gösterdiği gözükmektedir.

\section{Tüketim:}

Sağlıklı beslenmenin öncelik haline geldiği günümüzde, su ürünleri tüketimi en değerli besin öğelerinin başında geldiği birçok platformda konu uzmanları tarafından sıklıkla ifade edilmektedir. Özellikle diyet-perhiz listelerinde protein kaynağı olarak liste başında yer verilen su ürünlerinin, tüketimi konusunda etkin rol alan bazı faktörler vardır. Artan ve yaşlanan nüfus, ekonomik gelişim ve küreselleşme politikalarının yansıması, coğrafi yapı, kaynakların yoğun kullanımı ve üretim teknolojileri gibi faktörler, su ürünleri tüketiminin cazibesini arttıran unsur olduğu söylenebilir $(8,18,23)$. Ülkeler arasında, yıllık kişi başına tüketimi 1 kg'dan 100 kg'a kadar değişmektedir. Okyanus, deniz ve büyük iç su kaynaklarına yakın ülkelerde tüketim genellikle daha yüksektir (TAGEM 2019, Çımat ve Duran 2018). Genel olarak yapılan tüketim hesaplamalarında, dünyada su ürünleri tüketimi $20 \mathrm{~kg}$, Avrupa'da 24-25 $\mathrm{kg}$, Türkiye'de ise ortalama 6-8 kg olarak olduğu bildirilmektedir (19). Gelecekte kişi başı tüketimin, 2030 yılında ortalama $21,5 \mathrm{~kg}$ seviyesine yükseleceği öngörülmektedir. 2050 yılında dünya nüfusunun yaklaşı 10 milyara ulaşacağına ilişkin değerlendirmeler ışı̆̆ında artan nüfusa paralel olarak gıda ihtiyacının karşılanabilmesi için gıda ürünleri üretiminin de \% 70 civarında bir artış olması gerektiği vurgulanmaktadır $(8,15)$. Bu bağlamda talep artışına bağlı olarak bu sektörde de üretimin günden güne önem kazanacağı söylenebilir. 


\section{Ekonomik veriler:}

Su ürünleri ekonomik açıdan değerlendirildiğinde tüm dünyada yoğun arz ve talep seyri gösteren, buna bağl1 olarak ülkeler arasında ekonomik iş birliği süreçlerini geliştiren önemli konulardandır. Tüketim alışkanlıklarının en önemli belirleyici unsur olmasının yanında küreselleşme politikalarının yansıması olarak pazarlama kabiliyetinde gerçekleşen gelişme ülkelerin farklı su ürünlerine olan taleplerini de arttırmaktadır. Buna bağlı olarak avcılık ve yetiştiricilik yapan ülkelerin hem birbirleri arasında hem de avcılık ve yetiştiricilik kapasitesi düşük ya da yeterli olmayan ülkelerle yoğun su ürünleri ticari faaliyetleri olmaktadır.

Tablo-5 incelendiğinde Dünya su ürünleri ticaretinde önemli ithalatçı ülkelere bakacak olursak; ABD, Çin, Japonya, Fransa, İtalya, Almanya ve Güney Kore'dir. İhracat rakamları en yüksek olan ülkeler ise; Çin, Norveç, Vietnam, ABD, Tayland, Şili ve Danimarka'dır.

Tablo 5: Bazı ülkelerin su ürünleri ihracatı ve ithalatı (2017)

Table 5: The export and import of fisheries and aquaculture products of some countries (2017)

\begin{tabular}{lcccc}
\hline \multirow{2}{*}{ Ülkeler } & \multicolumn{2}{c}{ Íhracat } & \multicolumn{2}{c}{ İthalat } \\
\cline { 2 - 5 } & Miktar(Ton) & Değer (1000 \$) & Miktar(Ton) & Değer (1000 \$) \\
\hline Almanya & 901.309 & 2.900 .472 & 1.153 .316 & 5.751 .523 \\
ABD & 1.704 .658 & 6.224 .512 & 2.777 .117 & 21.715 .094 \\
Çin & 4.255 .401 & 20.572 .259 & 4.625 .127 & 10.707 .997 \\
Danimarka & 1.216 .563 & 4.889 .447 & 1.370 .401 & 3.776 .490 \\
Fransa & 347.747 & 1.178 .331 & 1.168 .286 & 6.725 .391 \\
Hollanda & 1.429 .222 & 5.288 .370 & 1.103 .228 & 4.301 .519 \\
İspanya & 1.183 .998 & 4.662 .247 & 1.757 .899 & 7.998 .176 \\
İsveç & 779.570 & 4.141 .322 & 736.292 & 4.932 .341 \\
İtalya & 157.159 & 825.988 & 1.111 .411 & 6.563 .005 \\
Japonya & 593.289 & 2.090 .013 & 2.418 .544 & 15.044 .535 \\
Güney Kore & 448.693 & 1.710 .416 & 1.466 .421 & 5.113 .163 \\
Norveç & 2.627 .962 & 11.306 .385 & 640.261 & 1.221 .336 \\
Polonya & 396.968 & 2.202 .794 & 585.141 & 2.329 .577 \\
Portekiz & 263.982 & 1.184 .734 & 534.659 & 2.393 .641 \\
Rusya & 2.222 .528 & 4.523 .125 & 616.603 & 1.980 .252 \\
Şili & 1.150 .222 & 5.993 .690 & 162.716 & 388.334 \\
Tayland & 1.355 .218 & 6.035 .793 & 1.919 .110 & 3.581 .985 \\
Türkiye & 162.762 & 862.014 & 264.580 & 453.988 \\
Vietnam & 1.822 .326 & 8.580 .758 & 625.363 & 1.754 .855 \\
\hline
\end{tabular}

Kaynak: BSGM 2020

İhracat ve ithalat rakamlarını değerlendirirken üretimin belirleyici olmasının yanında, işleme sonucu ikincil ürün pazarlama ve doğrudan aracılık yaparak ithalata bağlı ihracatın da gerçekleştiği konusunu vurgulamak gerekir. Ayrıca birçok ülkenin su ürünleri ithalat rakamlarının içeriğinde balık yemi olarak kullanılmak üzere balık unu ve yağ gibi unsurları ihtiva eden su ürünlerinin de yer aldığını belirtmek gerekir. Bu sebeple ülkemizde ve tüm dünyada da ithalat ve ihracat rakamlarını doğrudan tüketim açısından değerlendirmek eksik bir yaklaşım olabilir. Dış ticaret açısından en önemli konuma sahip olan su ürünleri; karides, ton balığı ve somondur $(5,6,19)$.

\section{Türkiye'de Su ürünleri Sektöründe Mevcut Durum}

Türkiye, üç tarafi denizlerle çevrili, birçok göl ve gölete sahip coğrafi özelliğiyle su ürünleri açısından büyük bir potansiyele sahip olan bir ülkedir. Şekil 1'de görülebileceği üzere, ülkemizdeki su ürünlerinin üretim alanı toplam tarım alanlarıyla yakın bir değere sahiptir (7). Mavi vatan tabiriyle anılan bu alanın büyüklüğüne rağmen, sektörün ekonomiye katkısı henüz yeterli düzeye ulaşmamıştır (4). 


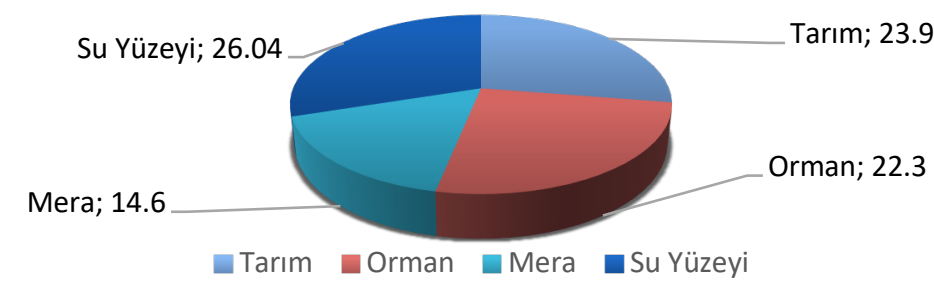

Şekil 1: Türkiye'nin toprak ve su yüzeyi varlığı ve dağılımı (milyon hektar) (7)

Figure 1: Turkey's soil and water surface assets and distribution (million hectares) (7)

Türkiye'nin su yüzey kaynakları incelendiğinde ise, üretim açısından denizlerden istifade edilecek alanın daha yüksek düzeyde olduğu (Şekil 2) görülmektedir (7).

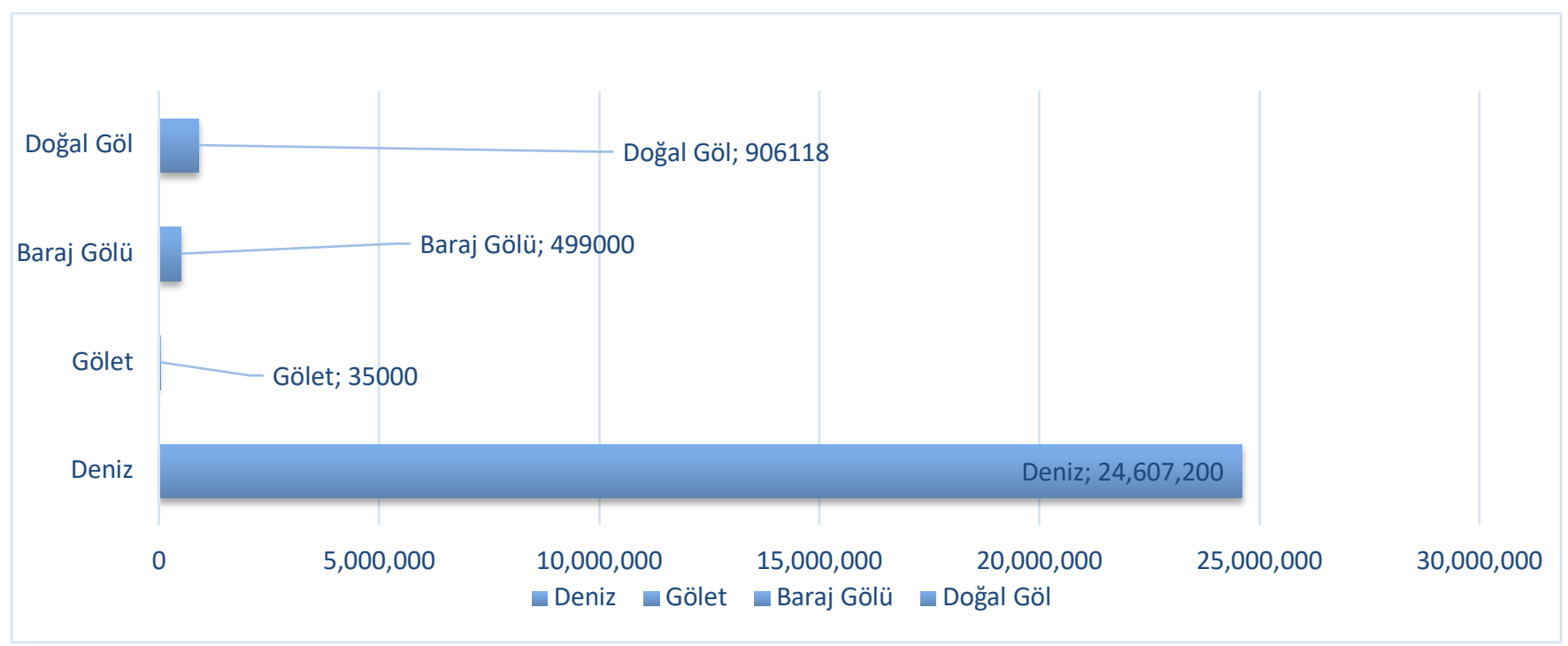

Şekil 2: Türkiye'nin su yüzeyi varlı̆̆ı ve dağılımı (ha) (7)

Figure 2: The water surface existence and distribution of Turkey (ha) (7)

Ekolojik olarak sahip olduğu uygun koşullar nedeniyle birçok türe sahip olan denizlerimiz ve iç sularımız, avcılık ve yetiştiricilik açısından zengin kaynaklar durumundadır. Karadeniz'de 247, Marmara Denizi'nde 200, Ege Denizi'nde 300 ve Akdeniz'de 500 balık türü bulunmaktadır. Ekonomik olarak değerlendirilen türlerin sayısı ise yaklaşık 100 civarındadır $(4,8)$.

Kalkınma planlarında yer verilerek üzerinde durulan önemli bir konu olan su ürünleri yetiştiriciliği, Türkiye açısından ekonomik potansiyeli gereği genel bir politika olarak benimsenmiştir. Su ürünlerinde sürdürülebilirliğin sağlanması amacıyla; doğal kaynakların etkin ve verimli kullanımı, yetiştiricilik ve açık deniz balıkçılığın geliştirilmesi konularını esas almaktadır. Bu kapsamda su ürünleri ıslah ve yetiştiriciliği, kaynakların doğru kullanımı, üretimin arttırılması, su ürünleri arz-talep dengesinin sağlanması, doğal su ürünleri stoklarının korunarak desteklenmesi, yeni istihdam imkânlarının oluşturulması ve yüksek miktarlarda döviz girdisi sağlayacak şekilde su ürünleri ihracatının geliştirilmesi büyük önem arz etmektedir $(4,8)$. 


\section{Üretim:}

Türkiye'nin su ürünleri avcılık üretimi yıllar itibarı ile dalgalı bir değişim gösterirken, yetiştiricilik üretimi sürekli bir artış eğilimindedir. Tablo-6 incelendiğinde Türkiye'de su ürünleri üretimi 2018 y1lında 628.631 ton olarak gerçekleşmiş, avcılıkla yapılan üretim 314.094 ton olurken, yetiştiricilik üretimi ise 314.537 ton olarak gerçekleşmiştir (22). 2019 yılında ise 836.524 tonluk üretim ile rekor bir üretim miktarına ulaşılmıştır. Bu üretimin 463.168 tonluk kısmı avcılık yoluyla elde edilirken, 373.356 tonluk kısmı ise yetiştiricilik yoluyla elde edilmiştir (6).

Tablo 6: Türkiye'de su ürünleri üretim miktarı (ton)

Table 6: The amount of fisheries and aquaculture production in Turkey (metric tons)

\begin{tabular}{cccccccc}
\hline \multirow{2}{*}{ Yıllar } & \multicolumn{3}{c}{ Avcllık (Ton) } & \multicolumn{3}{c}{ Yetiştiricilik (Ton) } & \multirow{2}{*}{ Toplam(Ton) } \\
\cline { 2 - 6 } & Deniz & İçsu & Toplam & Deniz & İçsu & Toplam & \\
\hline 2011 & 477.658 & 37.097 & 514.755 & 88.344 & 100.446 & 188.790 & 703.545 \\
2012 & 396.322 & 36.120 & 432.442 & 100.853 & 111.557 & 212.410 & 644.852 \\
2013 & 339.047 & 35.074 & 374.121 & 110.375 & 123.018 & 233.393 & 607.515 \\
2014 & 266.078 & 36.134 & 302.212 & 126.894 & 108.239 & 235.133 & 537.345 \\
2015 & 397.731 & 34.176 & 431.907 & 138.879 & 101.455 & 240.334 & 672.241 \\
2016 & 301.464 & 33.856 & 335.320 & 151.794 & 101.601 & 253.395 & 588.715 \\
2017 & 322.173 & 32.145 & 354.318 & 172.492 & 104.010 & 276.502 & 630.820 \\
2018 & 283.955 & 30.139 & 314.094 & 209.370 & 105.167 & 314.537 & 628.631 \\
2019 & 431.572 & 31.596 & 463.168 & 256.930 & 116.426 & 373.356 & 836.524 \\
\hline
\end{tabular}

Kaynak: BSGM 2020

Ülkemizde denizlerde ve içsularda avcılı̆̆ yapılan ve ekonomik olarak değerli olan türler; hamsi, sardalya, istavrit, palamut, lüfer, çaça, mezgit, tekir, barbunya, kalkan, deniz salyangozu, karidesler, midye, orkinos, sazan ve inci kefalidir.

Tablo 7'de avcılığı yapılan önemli deniz ürünlerinin 2018 ve 2019 yıllarındaki üretim miktarları ve değişim yüzdesine yer verilmiştir. Tabloden de görülebileceği gibi hamsi en dikkat çekici türdür. Türkiye'nin avcılık potansiyeli aynı zamanda yetiştiricilik açısından da çok önemli bir husustur. Çünkü balık yeminde kullanılan balık unu ve yağı, avc1lık yoluyla elde edilen su ürünlerinden elde edilmektedir (23).

Tablo 7: Türkiye'de avcıllı̆g yapılan önemli deniz ürünlerinin üretim miktar ve payları

Table 7: The production volumes and shares of major sea fisheries capture products of Turkey

\begin{tabular}{|c|c|c|c|c|c|}
\hline \multirow[b]{2}{*}{ Türler } & \multicolumn{2}{|c|}{2018} & \multicolumn{2}{|c|}{2019} & \multirow[b]{2}{*}{$\begin{array}{l}\text { 2018-2019 } \\
\text { \% Değişim }\end{array}$} \\
\hline & Miktar (ton) & $\begin{array}{c}\text { Toplam } \\
\text { İçindeki Payı } \\
(\%)\end{array}$ & $\begin{array}{l}\text { Miktar } \\
\text { (ton) }\end{array}$ & $\begin{array}{c}\text { Toplam } \\
\text { İçindeki Payı } \\
(\%)\end{array}$ & \\
\hline Hamsi & 96.452 & 34,0 & 262.544 & 60,8 & 172,2 \\
\hline Çaça & 20.057 & 7,1 & 38.078 & 8,8 & 89,8 \\
\hline Beyaz Kum Midyesi & 44.533 & 15,7 & 36.627 & 8,5 & $-17,8$ \\
\hline Palamut-Torik & 30.920 & 10,9 & 1.578 & 0,4 & $-94,9$ \\
\hline Sardalya & 18.854 & 6,6 & 19.119 & 4,4 & 1,4 \\
\hline İstavrit & 20.678 & 7,3 & 19.505 & 4,5 & $-5,7$ \\
\hline Mezgit & 6.814 & 2,4 & 8.941 & 2,1 & 31,2 \\
\hline Lüfer & 5.767 & 2,0 & 1.213 & 0,3 & $-79,0$ \\
\hline Deniz Salyangozu & 9.672 & 3,4 & 11.646 & 2,7 & 20,4 \\
\hline Tekir & 2.915 & 1,0 & 2.342 & 0,5 & $-19,7$ \\
\hline Barbunya & 1.399 & 0,6 & 1.719 & 0,4 & 21,5 \\
\hline $\begin{array}{l}\text { Diğer Balıklar ve Diğer } \\
\text { Deniz Ürünleri }\end{array}$ & 25.844 & 9,1 & 28.218 & 6,5 & 9,2 \\
\hline TOPLAM & 283.955 & 100 & 431.572 & 100 & 52,0 \\
\hline
\end{tabular}

Kaynak: BSGM 2020 
Tablo 8'de içsu ürünleri avcıllğı açısından önemli olan bazı türlerin yıllar itibariyle üretim miktarları gösterilmektedir.

Tablo 8: Türkiye'de içsu ürünleri avcılığı üretim miktarı (ton)

Table 8: The amount of production of inland fisheries capture in Turkey (tonnes)

\begin{tabular}{lllllllll}
\hline Türler & $\mathbf{2 0 1 2}$ & $\mathbf{2 0 1 3}$ & $\mathbf{2 0 1 4}$ & $\mathbf{2 0 1 5}$ & $\mathbf{2 0 1 6}$ & $\mathbf{2 0 1 7}$ & $\mathbf{2 0 1 8}$ & $\mathbf{2 0 1 9}$ \\
\hline Gümüş Balığ1 & 3.609 & 5.012 & 6.471 & 4.930 & 4.640 & 4.892 & 4.630 & 4.744 \\
Gümüşi Havuz B. & 5.090 & 5.495 & 5.408 & 6.745 & 7.652 & 7.035 & 6.134 & 6.555 \\
İnci Kefali & 9.621 & 9.600 & 8.310 & 8.850 & 9.950 & 9.830 & 9.945 & 9.970 \\
Kefal & 1.138 & 1.094 & 1.192 & 1.161 & 1.136 & 1.424 & 1.088 & 1.102 \\
Salyangoz & 1.193 & 1.431 & 1.547 & 733 & 1.317 & 1.156 & 1.521 & 1.828 \\
Sazan & 9.973 & 8.277 & 8.036 & 7.223 & 4.736 & 3.543 & 2.906 & 3.058 \\
\hline
\end{tabular}

Kaynak: BSGM 2020

Yıllar itibariyle avlanma miktarı değişiklik gösterse de avcılı̆̆ı yapılan diğer türlere kıyasla miktar olarak iç sularda en çok avcılığı yapılan tür, inci kefalidir. Ayrıca gümüşi havuz balığı, gümüş balığı, sazan, kefal ve salyangoz iç sularda avcıllık açısından önemli diğer türlerdir.

Avcılık potansiyelini, denizlerdeki tür ve miktar çokluğu ile birlikte avcılık kapasitesini belirleyen balıkçı gemileridir. Avrupa Birliği üye ülkeleri ile Türkiye'nin balıkçı gemi sayılarını karşılaştırmak gerekirse Türkiye'nin av filosunun rekabet açısından kısmen iyi olduğu Tablo-9 incelendiğinde görülecektir.

Tablo 9: Avrupa Birliği ülkelerinde balıkçı gemi sayıları (adet)

Table 9: The number of fishing vessels in the European Union countries (number)

\begin{tabular}{llllllllll}
\hline & $\mathbf{2 0 1 0}$ & $\mathbf{2 0 1 1}$ & $\mathbf{2 0 1 2}$ & $\mathbf{2 0 1 3}$ & $\mathbf{2 0 1 4}$ & $\mathbf{2 0 1 5}$ & $\mathbf{2 0 1 6}$ & $\mathbf{2 0 1 7}$ & $\mathbf{2 0 1 8}$ \\
\hline Yunanistan & 16.913 & 16.403 & 15.854 & 15.661 & 15.567 & 15.351 & 15.176 & 14.977 & 14.934 \\
İtalya & 13.431 & 13.023 & 12.696 & 12.594 & 12.424 & 12.300 & 12.260 & 12.250 & 12.059 \\
İspanya & 10.855 & 10.510 & 10.121 & 9.873 & 9.631 & 9.397 & 9.244 & 9.083 & 8.976 \\
Portekiz & 8.425 & 8.333 & 8.245 & 8.199 & 8.155 & 8.035 & 7.955 & 7.913 & 7.851 \\
Fransa & 7.216 & 7.205 & 7.138 & 7.120 & 7.062 & 6.904 & 6.833 & 6.510 & 6.379 \\
İngiltere & 6.460 & 6.389 & 6.360 & 6.303 & 6.276 & 6.232 & 6.197 & 6.151 & 6.046 \\
Diğer & 20.074 & 19.928 & 19.960 & 27.044 & 26.805 & 25.984 & 25.914 & 25.723 & 25.615 \\
AB Toplam & 83.374 & 81.791 & 80.374 & 86.794 & 85.920 & 84.203 & 83.579 & 82.607 & 81.860 \\
Türkiye & 17.440 & 17.165 & 16.998 & 16.437 & 15.877 & 15.680 & 15.663 & 15.406 & 15.352
\end{tabular}

Kaynak: BSGM 2020

Avcılık açısından gemi sayısı kadar, gemilerin boy ve avcılık kapasitesi de önemli konulardır. 12 m'den büyük gemilerin, daha fazla avlanma kapasitesini oluşturan özellikleri ile kıyıdan daha uzak alanlarda avlanabilme donanımlarına sahip olması avcılık açısından önemli hususlardandır. Bu açıdan, ülkemizin avcılık filosuna bakacak olursak, toplam av filosundaki gemi sayısı her ne kadar yüksek olsa da, avcılık yapan gemilerin çoğunluğu 12 m'nin altındaki gemilerden oluşmaktadır. Tablo-10'da yer alan Türkiye'nin 2019 yılı itibariyle mevcut balıkçı gemilerinin boy dağılımı ve adetlerini inceleyecek olursak; 12 m'nin altındaki gemi (deniz) sayısı:13726 (\%89,6), 12 m'nin üzerindeki gemi (deniz) sayısı:1586 (\%10,4). Ayrıca, denizde faaliyet gösteren 102 adet yardımcı gemi mevcuttur (6). 
Tablo 10: Türkiye'de balıkçı gemilerinin boy dağılımı (2019) (adet)

Table 10: Length distribution of fishing vessels in Turkey (2019) (number)

\begin{tabular}{lcccccccc}
\hline & \multicolumn{7}{c}{ Boy Grubu (m) } & \multirow{2}{*}{ Toplam } \\
\cline { 2 - 7 } Faaliyet & $\mathbf{0 - 4 , 9}$ & $\mathbf{5 - 7 , 9}$ & $\mathbf{8 - 9 , 9}$ & $\mathbf{1 0 - 1 1 , 9}$ & $\mathbf{1 2 - 1 9 , 9}$ & $\mathbf{2 0 - 2 9 , 9}$ & $\mathbf{3 0}+$ & \\
\hline Alan1 & & & & & & & \\
\hline Deniz & 700 & 8.970 & 3.256 & 800 & 849 & 465 & 275 & 15.315 \\
İçsu & 272 & 2.130 & 254 & 22 & 62 & 0 & 0 & 2.740 \\
Toplam & 972 & 11.100 & 3.510 & 822 & 911 & 465 & 275 & 18.055 \\
\hline
\end{tabular}

Kaynak: BSGM 2020

Ülkemizin mevcut avcılık filosunu genel avcılık açısından değerlendirecek olursak, geniş ve uzak sahalarda avcılık yapan gemi sayısının daha az olması, kıyı şeridine yakın alanlarda av baskısı oluşturmakla birlikte aynı alandan elde edilen üretimin tür ve miktar açısından da daha kısıtlı kalınması gibi dezavantajları beraberinde getireceği söylenebilir. Daha geniş alanlarda ve derinliklerde avcılık yapma kapasitesine sahip olan 12 m'nin üzerindeki gemilerin avcılık üretimi açısından tür ve miktar olarak elde ettiği üretim ise, toplam avcılık üretimi açısından daha fazla olmaktadır. Türkiye'nin av fillosunun çoğunluğunun 12 m'nin altında olması, kıyı balıkçılığı açısından önemli olsa da, toplam üretimde daha çok belirleyici olan 12 m'den büyük gemilerin oluşturduğu potansiyeli sağlaması mümkün değildir.

Su ürünleri yetiştiriciliğinin üretim miktarını, tesislerin fiziki kapasiteleri belirlemektedir. Ülkemizde 2019 yılı itibariyle mevcut tesislerin kapasite miktarlarıla birlikte toplam adetleri Tablo 11'de gösterilmiştir.

Tablo 11: Türkiye'de su ürünleri yetiştiricilik tesislerinin kapasitelerine göre dağılımları (2019)

Table 11: The distribution by the capacities of aquaculture facilities in Turkey (2019)

\begin{tabular}{lccc}
\hline Grup & Kapasite Grubu (Ton) & Tesis Sayısı (Adet) & $\begin{array}{c}\text { Toplam Proje } \\
\text { Kapasitesi(Ton/Yıl) }\end{array}$ \\
\hline \multirow{4}{*}{ Deniz } & $0-50$ & 154 & 3.540 \\
& $51-100$ & 18 & 1.535 \\
& $101-250$ & 15 & 2.594 \\
& $251-500$ & 59 & 19.976 \\
$501-1000$ & 88 & 77.514 \\
& $1001>$ & 100 & 201.070 \\
\hline İçsu & $0-50$ & $\mathbf{4 3 4}$ & $\mathbf{3 0 6 . 2 2 9}$ \\
& $51-100$ & 1.178 & 19.110 \\
& $101-250$ & 106 & 9.399 \\
& $251-500$ & 185 & 36.674 \\
& $501-1000$ & 109 & 47.879 \\
& $1001>$ & 112 & 96.081 \\
& TOPLAM & 3 & 7.400 \\
\hline \multirow{4}{*}{ Deniz+İcsu } & $0-50$ & $\mathbf{1 . 6 9 3}$ & $\mathbf{2 1 6 . 5 4 3}$ \\
& $51-100$ & 1.332 & 22.650 \\
& $101-250$ & 124 & 10.934 \\
& $251-500$ & 200 & 39.268 \\
& TOPLAM & 168 & 67.855 \\
\cline { 2 - 4 } & $1001>$ & 200 & 173.595 \\
& & 103 & 208.470 \\
\hline
\end{tabular}

Kaynak: BSGM 2020

Toplam yetiştiricilik tesislerinin \%62,62'sini 0-50 ton kapasiteli tesisler oluşturmaktadır. Düşük kapasiteli tesislerde yapılan üretim, toplam üretimdeki payı \%4,33'lük orana karşılık gelmektedir. 1001 ton ve üzeri tesis sayısına 
baktığımızda ise toplam tesis sayısının \%4,84'lük kısmını oluşturduğu görülmektedir. Toplam üretimdeki payı ise \%39,87 oranındadır. Yıllık toplam üretimi sürekli artış gösteren yetiştiriciliğin ana unsuru olan yetiştiricilik tesislerinin kapasite artırımının sağlanması ve yeni kurulacak tesislerde ise üretim kapasitelerinin 50 ton üzeri olması, toplam üretimin arttırılması için elzemdir. Ayrıca mevcut üretim yapılan sahalarda atıl kalan kapasitenin de üretime kazandırılması gibi hususlarda yapılacak çalışmalar yetiştiriciliğin gelişimi ve büyümesi açısından önemli kazanımlar sağlayacaktır $(6,19)$.

2010-2019 yılları arasında deniz ve içsu yetiştiricilik üretim miktarlarındaki değişim ve üretim değeri Tablo 12 'de sunulmuştur.

Tablo 12. Türkiye'de deniz ve içsu yetiştiricilik üretim miktarı ve üretim değeri

Table 12: Marine and inland aquaculture production amount and value in Turkey

\begin{tabular}{ccccc}
\hline Yıllar & \multicolumn{2}{c}{ Üretim Miktarı } & \multicolumn{2}{c}{ Üretim Değeri } \\
\cline { 2 - 5 } & $\begin{array}{c}\text { Toplam Üretim } \\
\text { (ton) }\end{array}$ & $\begin{array}{c}\text { Önceki Yıla } \\
\text { göre artı̧ (\%) }\end{array}$ & Toplam Değer (TL) & $\begin{array}{c}\text { Önceki Yıla } \\
\text { göre artış (\%) }\end{array}$ \\
\hline 2010 & 167.141 & - & 1.066 .778 .600 & - \\
2011 & 188.790 & 13,0 & 1.270 .028 .140 & 19,1 \\
2012 & 212.410 & 12,5 & 1.605 .293 .700 & 26,4 \\
2013 & 233.393 & 9,8 & 1.704 .471 .151 & 6,2 \\
2014 & 235.133 & 0,7 & 2.160 .070 .890 & 26,7 \\
2015 & 240.334 & 2,2 & 2.569 .208 .590 & 18,9 \\
2016 & 253.395 & 5,4 & 3.239 .320 .980 & 26,1 \\
2017 & 276.502 & 9,1 & 4.049 .199 .270 & 38,0 \\
2018 & 314.537 & 13,8 & 5.606 .828 .410 & 37,23 \\
2019 & 373.356 & 18,7 & 7.694 .124 .480 & \\
\hline
\end{tabular}

Kaynak: BSGM 2020

2019 yılında gerçekleşen toplam üretim, 2010 yılındaki toplam üretimle kıyasladığımızda \%123,37’lik artış gerçekleştiği görülmektedir. Üretim değeri açısından 2010 yılında gerçekleşen üretimin, 2019 yılındaki gerçekleşen üretimle karşılaştırdığımızda ise \%621,24'lük bir artışın söz konusudur. Bu durum genel olarak ülkemizin yetiştiricilik açısından gösterdiği gelişimin, ekonomik açıdan da önemli bir hacme sahip olduğunu ifade etmektedir.

Ülkemizde yetiştiricilik açısından önemli olan türler olarak karşımıza çıkan Alabalık, Çipura ve Levrek 'in yıllara bağlı üretim miktarlarındaki değişimler Tablo 13'de gösterilmektedir.

Tablo 13. Türkiye'de yetiştiriciliği en çok yapılan türlerin üretim miktarları (ton)

Tablo 13: The production amounts of the most commonly cultured species in Turkey (metric tons)

\begin{tabular}{cccccc}
\hline Yllar & \multicolumn{3}{c}{ Alabalık } & Çipura & Levrek \\
\cline { 2 - 4 } & İçsu & Deniz & Toplam & & \\
\hline 2012 & 111.335 & 3.234 & 114.569 & 30.743 & 65.512 \\
2013 & 122.873 & 5.186 & 128.059 & 35.701 & 67.913 \\
2014 & 107.983 & 5.610 & 113.593 & 41.873 & 74.653 \\
2015 & 101.166 & 6.872 & 108.038 & 51.844 & 75.164 \\
2016 & 101.297 & 5.716 & 107.013 & 58.254 & 80.847 \\
2017 & 103.705 & 5.952 & 109.657 & 61.090 & 99.971 \\
2018 & 104.887 & 9.610 & 114.497 & 76.680 & 116.915 \\
2019 & 116.053 & 9.692 & 125.745 & 99.730 & 137.419 \\
\hline
\end{tabular}


Tabloyi incelediğimizde 2012 yılından 2019 yılına kadar ki süreçte iç sularda yetiştiriciliği yapılan alabalık üretiminde çok büyük miktarlarda olmasa da inişli ve çıkışlı bir değişim gösterdiği görülmektedir. Denizlerde yapılan alabalık yetiştiriciliğinde ise sürekli artış olmuştur. 2012 yılında denizlerde yetiştiriciliği yapılan alabalık üretiminin, 2019 yılında gerçekleşen miktarla kıyasladığımızda \%199,69'luk oranla artışın gerçekleştiği gözükmektedir. Aynı yıllarda gerçekleşen değişimin çipura da \%224,39' lik artış oranı, levrekte ise \%109,76'lık artış oranı ile gerçekleşmiştir.

Yetiştiricilik açısından ülkemiz coğrafi bölgeleri ilişkin bilgiler Şekil 3’te sunulmuştur (6).

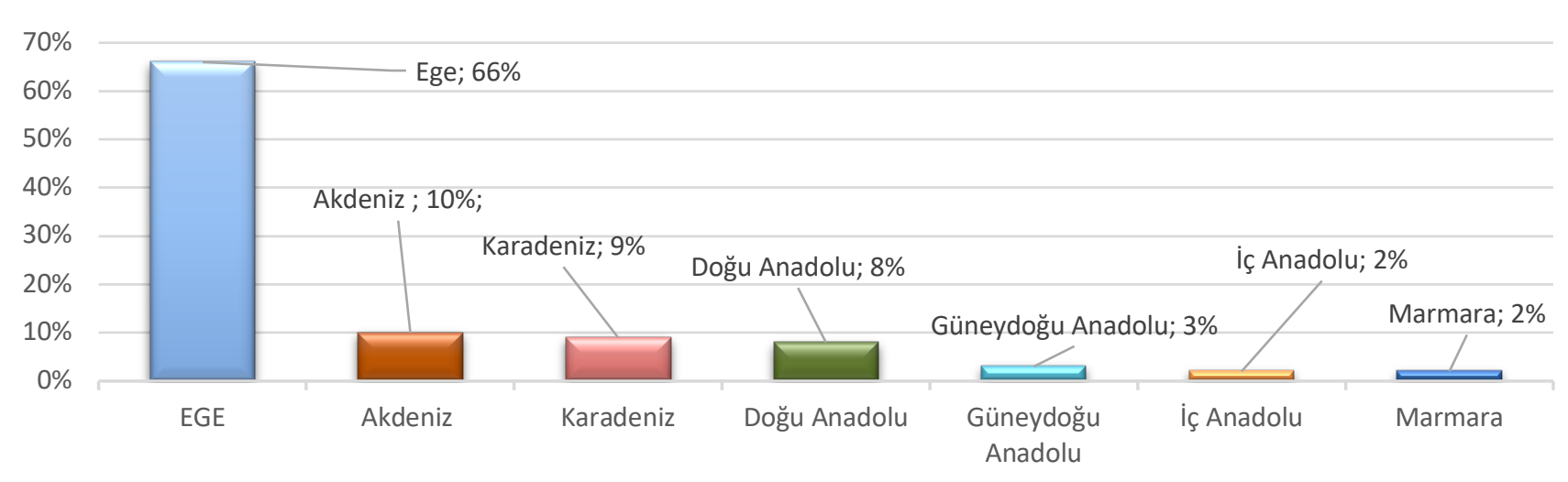

Şekil 3: Türkiye'de yetiştiricilik üretiminin coğrafi bölgelere göre dağılımı (\%)

Figure 3: Distribution of aquaculture production by geographical regions in Turkey (\%)

Bölgelere göre su ürünleri yetiştiricilik üretim oranlarına bakacak olursak \%66'llk oranla en fazla üretimin Ege bölgesinde gerçekleştiği görülmektedir. Akdeniz bölgesinde \%10, Karadeniz bölgesinde \%9, Doğu Anadolu bölgesinde \%8, Güneydoğu Anadolu bölgesinde \%3, İç Anadolu ve Marmara bölgelerinde ise \%2'lik üretim payı söz konusudur (6).

\section{Türkiye'de su ürünleri sektöründe maliyet yapısı:}

Su ürünleri sektöründe maliyeti oluşturan masraf unsurları incelendiğinde, avcılık açısından en önemli maliyet unsurunun akaryakıt giderleri ile işçilik olduğu gözükmektedir. Özellikle deniz balıkçılığı yapan gemilerin toplam giderlerinin ortalama olarak \%36’ü akaryakıt, \%30'si işgücü ödemelerinden meydana gelmektedir. Girdi maliyetleri yetiştiricilik açısından ele alındığında ise; en önemli masraf unsuru yem giderleridir (23). Su ürünleri yetiştiriciliğinde üretimi meydana getiren avcılık ve yetiştiricilik arasında sürdürülebilirlik bağlamında önemli bir ilişki söz konusudur. Yetiştiricilik açısından en önemli konu olan balık yemlerinde kullanılan balık unu ve yağının kaynağı avcılık yoluyla elde edilen ürünlerle sağlanıyor olmasıdır. Türkiye'de avcılık yoluyla elde edilen üretim \%70'lik kısmının insan tüketimine sunulması ve doğal olarak yetiştiricilik açısından ihtiyacı karşılayamamasından ötürü sektörü farklı alternatiflere yöneltmek durumunda kalmıştır. Balık unu ve yağı gibi temel hammaddelerin temini için ithalat zorunluluğu oluşmaktadır. Dışa bağımlılık, hem tedarik sürecinde riskler oluşturmakta hem de girdi maliyetlerinde yüksek fiyatları beraberinde getirmektedir. Mevcut ihtiyaç avcılık arttırılarak karşılanmak istendiği takdirde, av baskısının oluşturacağı olumsuz süreç, avcılığın sürdürülebilirliği açısından daha fazla risk anlamına geldiği için ithalat süreci kaçınılmaz olmaktadır $(18,19,23)$.

\section{Türkiye’de su ürünleri pazarlama yapısı ve pazarlamada yaşanan sorunlar:}

Türkiye'de avcılık yapan gemilerin büyük çoğunluğu 12 metrenin altındaki gemilerdir. Bu gemilerin av miktarı, avcılık üretimi içerisinde düşük düzeydedir. Doğal olarak bu grup içerisinde yer alan üreticilerin sosyoekonomik durumları zayıftır. Yetiştiricilik yapan işletmelerde de durum benzerdir. Su ürünleri yetiştiriciliği yapan 
tesislerin çoğunluğu yıllık 50 ton'dan daha düşük kapasiteli işletmelerdir. Bu tesislerinde toplam yetiştiricilik içerisindeki payı çok düşük oranlara tekabül etmektedir. Daha büyük kapasiteli işletmelerin ise hem üretim miktarı hem de ciroları daha yüksek olup, doğal olarak sektör içerisinde ve sektöre paydaşlar üzerinde tesiri daha fazla olmaktadır $(6,23)$. Su ürünleri yetiştiriciliği yapan üreticiler, bizzat kendileri veya aracılar vasıtasıyla komisyonculara getirdikleri su ürünlerini, müzayede yoluyla balık halinde satışa sunarlar. Buradaki satış fiyatı tespiti tür, kilo, adet, kasa ve tazelik gibi ölçütler kullanılarak yapılmakta ve açık arttırma usulü gerçekleşmektedir. Yine üretim miktarı ve arz-talep dengesi gibi faktörler fiyatlar üzerine etki eden önemli hususlar arasında yer alır. Ayrıca çoğu zaman üretici tarafindan getirilen balıklar komisyoncular tarafından belli bir süre buzhane de muhafaza edilerek, ileri bir tarihte müzayede çıkartılır. Bu süreçte doğal olarak pazarlama fiyatına etki etmektedir. Taze tüketim ve mevsimsel tüketim gibi unsurlarda fiyatlarda dalgalanma etkisi yapmaktadır. Nakliye giderlerinin de girdi maliyetleri içerisinde yer almasına bağlı olarak, Su ürünleri fiyatlarında bölgeler arasında da farklılık görülmektedir. Yetiştiricilik fiyatlarını doğrudan etkileyen en önemli faktör ise yem fiyatlarındaki değişimlerdir. Yem ham maddelerinin genellikle ithal ediliyor olması, döviz kurlarındaki dalgalanmalara bağlı olarak maliyetlerin artışlarına sebebiyet verebilmekte, bunun sonucu da son ürün satışına yansımaktadır (23). Türkiye'de su ürünleri sektörüne hitap eden 210 su ürünleri işleme fabrikası, 13 balık unu-yağ 1 tesis, 3 insan tüketimi amacıyla balık yağı üretim tesisi ve 23 balık yemi fabrikası bulunmaktadır (19).

\section{Su ürünleri dış ticaretinde mevcut durum:}

Türkiye'nin su ürünleri sektöründe dış ticarette mevcut durumu Tablo-14'te gösterilmiştir. Tablo incelendiğinde Türkiye'nin hem ihracat yapan hem de ithalat yapan bir ülke olduğu görülmektedir.

Tablo 14: Türkiye'nin su ürünleri sektöründe dış ticaret durumu

Table 14: Turkey's foreign trade situation in the fisheries and aquaculture sector

\begin{tabular}{ccccccc}
\hline \multirow{2}{*}{ Yıllar } & \multicolumn{3}{c}{ IHRACAT } & \multicolumn{3}{c}{ iTHALAT } \\
\cline { 2 - 7 } & Miktar(Ton) & Değer (\$) & Değer (TL) & Miktar(Ton) & Değer (\$) & Dĕ̆er (TL) \\
\hline 2011 & 66.738 & 395.306 .914 & 664.333 .252 & 65.698 & 173.886 .517 & 290.826 .203 \\
2012 & 74.006 & 413.917 .190 & 744.907 .572 & 65.384 & 176.402 .894 & 317.626 .975 \\
2013 & 101.063 & 568.207 .316 & 1.083 .243 .678 & 67.530 & 188.068 .388 & 359.490 .196 \\
2014 & 115.381 & 675.844 .523 & 1.481 .211 .383 & 77.551 & 198.273 .838 & 435.961 .472 \\
2015 & 121.053 & 692.220 .595 & 1.879 .701 .163 & 110.761 & 250.969 .660 & 685.467 .749 \\
2016 & 145.469 & 790.303 .664 & 2.398 .269 .090 & 82.074 & 180.753 .629 & 548.878 .092 \\
2017 & 156.681 & 854.731 .829 & 3.128 .112 .446 & 100.444 & 230.111 .248 & 841.383 .610 \\
2018 & 177.500 & 951.793 .070 & 4.578 .607 .932 & 98.315 & 188.965 .220 & 898.860 .692 \\
2019 & 200.226 & 1.025 .617 .723 & 5.818 .776 .189 & 90.684 & 189.438 .745 & 1.076 .277 .706 \\
\hline
\end{tabular}

Kaynak: BSGM 2020

2011 yılında 66.738 ton gerçekleşen su ürünleri ihracatı 2019 yılında 200.226 ton olarak gerçekleşerek, \%200,01'lik bir artış göstermiştir. Aynı yıllar itibariyle ithalat miktarı ise \%38,03'lük artış oranında değişime sahiptir. İhracat rakamlarının, ithalat rakamlarından yüksek olması dış ticaret açısından pozitif bir dengenin söz konusu olduğunu göstermektedir. İhracat ve ithalat miktarlarının parasal hacmi de sürekli artış göstermiş̧ir. 2019 yılında su ürünlerinde 1.025.617.723\$'lık ihracat rakamına ulaşılmış olup aynı y1l içerisinde 189.438.745\$'llk ithalat gerçekleşmiştir.

İhracat açısından önemli olan türler; alabalık, çipura, levrek, orkinos ve hamsidir. İthalat kapsamında ise uskumru gibi düşük değerli ürünler ile balık yeminde hammadde olarak kullanılmakta olan türler vardır $(6,21)$. 


\section{Türkiye su ürünleri sektöründe örgütlenme, destekleme politikalarında mevcut durum ve sorunlar}

\section{Örgütlenme:}

Su ürünleri kooperatifleri, tüm dünya da yaygın olarak kurulan örgütlenme biçimidir. Hemen hemen her ülkede mevcuttur. Gelişmekte olan ülkelerde balıkçılar, rekabet, destekleme ve teşvik, eğitim ve dayanışma, sürdürülebilirlik gibi hususlarda aşama kat edebilmek için kooperatifler, üretici birlikleri, dernekler gibi kuruluşlar altında bir araya gelmişlerdir (26). Ülkemizde birçok tarım ve hayvancılık faaliyetinde olduğu gibi su ürünleri sektöründe de üreticilerin kahir ekseriyetini küçük ölçekli üreticiler oluşturmaktadır. Avcılık, yüksek yoğunlukta kıyı balıkçılığına uygun küçük teknelerle gerçekleştirilirken, yetiştiricilik faaliyetleri ise küçük ölçekli aile tipi işletmelerden oluştuğu gözükmektedir(17, 28). Türkiye'de, 1163 sayılı kanuna istinaden kurulan 565 kooperatif su ürünleri alanında faaliyet göstermekte ve 30.559 balıkçının bu kooperatiflere üyeliği bulunmaktadır $(2,23,25)$. Su Ürünleri Kooperatifleri Merkez Birliği, 2004 yılında kurulmuştur. Birliğin amacı; ortak birliklerin ve bunlara bağlı kooperatiflerin su ürünleri avcılık faaliyeti gerçekleştirmesi, üretim, işleme ve pazarlama konularında ortak menfaatleri gözeterek, eğitim çalışmalarında bulunmak, sektöre ilişki yatırım faaliyetlerine katkıda bulunmak olarak ifade edilebilir (23). Su Ürünleri Yetiştiricileri Üretici Merkez Birliği ise 5200 sayılı Tarımsal Üretici Birlikleri Kanunu hükümlerine göre 2009 yılında kurulmuş olan üretici teşkilatlanmasıdır. Birliğin genel amacı; bünyesinde yer alan birliklerin işbirliğini sağlayarak, ulusal düzeydeki su ürünleri üretim planlanma hedeflerine ulaşılması ve pazarlamada karşılaşılan sorunların çözülmesi konularında, uyum ve eşgüdüm sağlayacak kurallar oluşturmak. Uyulması gereken esaslar konusunda üyelerini bilgilendirme ve yönlendirmeler yapmak, üyelerinin ortak çıkarlarını da gözeterek sektörün gelişimine katkı sunmaktır $(2,23)$. Kooperatif ve üretici birliği örgütlerine üye olan balıkçı ve yetiştirici sayıları oldukça iyi olmasına rağmen, girdi tedariki, pazarlama ve karşılaşılan sorunların çözümünde üretici birlikleri ve kooperatiflerin etkinliği azdır. Ayrıca kooperatif ve birlikler aracılığılla pazarlama imkânı olmadığından, ürün fiyatlarının belirleme etkinliğinde bu örgütlerin etkisi zayıftır (23).

\section{Desteklemeler:}

Tarım ve Orman Bakanlı̆̆ desteklemeleri: Su ürünleri sektörüne yönelik destekleme tedbirleri; üretimin artırılması, yaygınlaştırılması, avcılıkta balık stoklarının korunması ve üreticilerin girdi maliyetlerinin düşürülmesi hedeflenerek 2003 yılında hayata geçirilmiştir. Tablo 15'de 2003-2019 yılları arasında su ürünleri yetiştiricilik desteklemeleri gösterilmektedir.

Tablo 15: Türkiye'de su ürünleri yetiştiricilik desteklemeleri

Table 15: The aquaculture subsidies in Turkey

\begin{tabular}{ccccc}
\hline Yıllar & $\begin{array}{c}\text { Toplam Yetiştiricilik } \\
\text { Üretim Miktarı (ton) }\end{array}$ & $\begin{array}{c}\text { Desteklenen } \\
\text { Üretim Miktarı } \\
\text { (Ton) }\end{array}$ & $\begin{array}{c}\text { Desteklenen Üretimin } \\
\text { Toplam Üretim } \\
\text { Içindeki Payı (\%) }\end{array}$ & $\begin{array}{c}\text { Ödenen Destek Tutarı } \\
\text { (Milyon TL) }\end{array}$ \\
\hline 2003 & 79.943 & 7.219 & 9,0 & 1,1 \\
2004 & 94.010 & 26.290 & 28,0 & 10,5 \\
2005 & 118.277 & 39.513 & 33,4 & 38,7 \\
2006 & 128.943 & 63.781 & 49,5 & 58,9 \\
2007 & 139.873 & 92.615 & 66,2 & 89,7 \\
2008 & 152.186 & 106.757 & 70,1 & 116,1 \\
2009 & 158.729 & 120.299 & 75,8 & 147,5 \\
2010 & 167.141 & 150.461 & 90,0 & 180,7 \\
2011 & 188.790 & 172.513 & 91,4 & 101,8 \\
2012 & 212.410 & 147.907 & 69,6 & 104,3 \\
2013 & 233.394 & 165.413 & 70,9 & 97,7 \\
2014 & 235.133 & 152.284 & 64,8 & 96,8 \\
2015 & 240.334 & 150.642 & 62,7 & 43,1 \\
2016 & 253.395 & 70.476 & 27,8 & 51,9 \\
2017 & 276.502 & 72.324 & 26,2 & 52,5 \\
2018 & 314.537 & 71.177 & 22,6 & 65,7 \\
2019 & 373.356 & 69.067 & 18,5 & $1.349,8$ \\
\hline
\end{tabular}


Tabloda da görüldüğü gibi, 2003-2019 yılları arasında üreticilere, toplam üretimin \%49,9’luk kısmına, toplamda 1.349,8 milyon TL destekleme yapılmıştır. Yaygın olarak yetiştiriciliği yapılan alabalık, çipura ve levrek türleri yanında yeni kültüre alınan türlere de üretimin kilogramı başına destekleme ödemeleri yapılmış, ayrıca yavru balık üretimine de destek verilmiştir. 2009 yılından itibaren tesis başına 2 bin tonun üzerindeki üretime, 2012 yılından itibaren 500 ton üzerindeki üretime destek verilmemiştir. 2013 yılından itibaren yavru balık desteği, 2016 yılından itibaren çipura ve levrek desteği kaldırılmıştır $(6,23,30)$.

Av baskısını azaltmak ve balıkçılığın sürdürülebilirliğini temin etmek amacıyla 2012 yılında, gemilerini avcılıktan çıkarmak isteyen balıkçılara gemi boyuna göre destekleme uygulaması yapılmış olup, uygulama esnasında geri alınan gemi sayısı ve gemi sahiplerine ödenen destekleme tutarları Tablo 16'da gösterilmiştir.

Tablo 16: Türkiye'de avcılıktan çıkarılan balıkçı gemilerine ödenen destekleme

Table 16: Buyback subsidies of fishing vessels removed from fishing in Turkey

\begin{tabular}{ccc}
\hline Yıllar & Geri Alınan Gemi Sayısı (adet) & Ödenen Tutar (TL) \\
\hline 2013 & 364 & 61.984 .800 \\
2014 & 456 & 53.921 .050 \\
2015 & 191 & 22.471 .000 \\
2017 & 214 & 22.426 .063 \\
2018 & 39 & 4.087 .058 \\
\hline TOPLAM & 1.264 & 164.889 .970 \\
\hline
\end{tabular}

Kaynak: BSGM 2020

2012-2018 yıllarında $10 \mathrm{~m}$ ve üzeri boylarda 1.264 adet balıkçı gemisi ruhsatları iptal edilerek filodan çıkarılmıştır. Bu balıkçılara yaklaşık 165 milyon TL destekleme ödemesi yapılmıştır. Uygulama 2018 yılında sonlandırılmıştır (23).

13.09.2017 yılında Resmi Gazete 'de yayınlanan 30179 sayılı Geleneksel kıyı balıkçılı̆̆ının kayıt altına alınması ve desteklenmesi tebliği ile kıyı balıkçılığı yapan gemiler destekleme kapsamına alınmıştır (Tablo 17).

Tablo 17. Türkiye'de geleneksel kıyı balıkçılığı desteklemeleri

Table 17: The subsidies of traditional coastal fishing in Turkey

\begin{tabular}{lllllll}
\hline \multirow{2}{*}{ Yıllar } & \multicolumn{2}{l}{ Faydalanan Gemi Sayısı } & & \multicolumn{3}{l}{ Toplam Destekleme Tutarı (TL) } \\
\cline { 2 - 6 } & Deniz & Íçsu & TOPLAM & Deniz & Íçsu & TOPLAM \\
\hline 2017 & 7.525 & 1.237 & 8.762 & 6.037 .00 & 946.500 & 6.983 .500 \\
2018 & 8.537 & 1.760 & 10.297 & 6.857 .750 & 1.338 .750 & 8.196 .500 \\
2019 & 9.805 & 2.464 & 12.269 & 10.346 .250 & 2.484 .500 & 12.830 .750 \\
\hline
\end{tabular}

Kaynak: BSGM 2020

2017 yılında küçük ölçekli balıkçı gemisi sahibi 8.762 balıkçıya 6.983 .500 TL ödeme yapılmıştır. 2018 yılında 10.297 balıkçıya 8.196 .500 TL, 2019 yılında ise 12.269 balıkçıya 12.830 .750 TL destekleme ödemesi gerçekleşmiştir. Toplamda 28.010.750 TL destekleme ödemesi yapılmıştır $(6,23)$.

Tablo 18'de Tarım ve Orman Bakanlığının 2020 yılı su ürünleri desteklemeleri görülmektedir (24). 
Tablo 18. Tarım ve Orman Bakanlığı su ürünleri yetiştiricilik desteklemeleri (2020)

Table 18: Aquaculture subsidies by the Ministry of Agriculture and Forestry (2020)

\section{Su Ürünleri Desteği}

\begin{tabular}{|c|c|c|c|}
\hline 1 & Alabalık (kg) & 350.000 kg'a kadar (350.000 kg dahil) & 0,75 \\
\hline 2 & Yeni Türler (kg) & 350.000 kg'a kadar (350.000 kg dahil) & 1,50 \\
\hline 3 & Kapal1 Sistem Üretim (kg) & $350.000 \mathrm{~kg}$ 'a kadar (350.000 kg dahil) & 1,50 \\
\hline 4 & Kilogram Üstü Alabalık Üretimi (kg) & 350.000 kg'a kadar (350.000 kg dahil) & 1,50 \\
\hline 5 & Midye $(\mathrm{kg})$ & $350.000 \mathrm{~kg}$ 'a kadar (350.000 kg dahil) & 0,10 \\
\hline 6 & Sazan (kg) & $350.000 \mathrm{~kg}$ 'a kadar (350.000 kg dahil) & 0,50 \\
\hline 7 & $\begin{array}{l}\text { Hastalıktan Ari Kuluçkahane Damızlık } \\
\text { Alabalık Desteği (adet) }\end{array}$ & 10.000 adet'e kadar ( 10.000 adet dahil) & 60,00 \\
\hline 8 & $\begin{array}{l}\text { Toprak Havuzlarda Balık Yetiştiriciliği } \\
(\mathrm{kg})\end{array}$ & 30.000 kg'a kadar (30.000 kg dahil) & 1,00 \\
\hline
\end{tabular}

Kaynak: TOB 2020

2020 yılında Tarım ve Orman Bakanlığı tarafından su ürünleri sektörüne verilen desteklemelerin yanında Tarım ve Kırsal Kalkınmayı Destekleme Kurumu(TKDK) koordinasyonunda uygulanan IPARD programları da, su ürünleri sektöründeki işletmelere desteklemeler sağlamaktadır. Üretimi teşvik açısından son derece önemli olan desteklemelerin, üreticilerin girdilerini azaltmasının yanında üretimde sürdürülebilirliğin sağlanması açısından elzem bir konudur. Bu anlamda yetkili otorite olarak Tarım ve Orman Bakanlığı hem düzenleme ve denetleme hem de destekleme politikalarıyla, sektörün gelişimine önemli katkı vermektedir (6).

Diğer Desteklemeler: 1 Ocak 2004 yılından itibaren, Ulaştırma ve Altyapı Bakanlığg tarafından sağlanan Özel Tüketim Vergisi (ÖTV) sıfırlanmış yakıt kullanımı, balıkçı gemileri açısından da önemli destekleme kalemlerindendir. 20042019 yılları arasında balıkçı gemilerinin kullandığı yakıttan alınmayan ÖTV'nin toplam tutarı 2.05 milyar TL civarındadır $(6,23)$. Ülkemizde 2004 yılından itibaren başlayan iyi tarım uygulamaları desteklemeleri kapsamına 11.07.2011 tarih ve 2011/8 sayılı uygulama genelgesiyle su ürünleri yetiştiriciliği de dâhil edilmiştir. Üretimin artış1 kadar çevreye duyarlı ve kalite yönetimi esaslarını dikkate alınması konusunun işlendiği iyi tarım uygulamalarının, su ürünleri kaynaklarının korunması açısından da ayrıca bir öneme sahip olduğu belirtilmelidir $(3,18)$. Girişimcilik destek programı kapsamında, su ürünleri sektöründe faaliyet gösteren işletmeler KOSGEB desteklerinden faydalanabilmektedirler. İhracat rakamları sürekli artış gösteren su ürünleri sektöründe faaliyet gösteren işletmeler, ihracat sürecinde karşılaştıkları finansman gereksinimlerini, Türk Eximbank'ın sağladığı ihracat kredileri ile karş1lamaları mümkündür (17). 10 Şubat 2018 tarihli ve 30328 sayılı Resmi Gazete' de yayımlanmış olan 2018/11188 karar sayılı tebliği ile yürürlüğe konulmuş olan, T.C. Ziraat Bankası A.Ş. tarafından üreticilere dönük gerçekleşen düşük faizli yatırım ve işletme kredisi uygulaması vardır. Bu kredilerden su ürünleri üreticilerinin de finansman ihtiyaçlarını karşılamak amacıyla yararlanabilmeleri söz konusudur $(6,17)$.

Su ürünleri sigortaları: Su ürünleri sigortaları, işletmelerde gelir kaybı ve finansal istikrarı sağlayacak şekilde, risk yönetimi açısından son derece önemli bir risk transfer aracıdır. Su ürünleri sigorta ürünlerinin geliştirilmesinde, risklerin belirsizliği ve meydana gelebilecek risklerin sonucunda oluşabilecek maddi kayıpların tahmin edilemez olması gibi birtakım engeller vardır. $\mathrm{Bu}$ nedenle, sigorta kullanılabilirliği genel olarak sınırlı kalmıştır. Su ürünleri yetiştiricilerinin risk kategorilerine uygun şekilde nitelendirilmesi, başarılı bir programın geliştirilebilmesi açısından çok önemlidir. Su ürünleri sigorta uygulamaları, 2006 yılında faaliyetine başlayan tarım sigortaları havuzu ve TARSIM tarafından sağlanan devlet destekli sigorta uygulamaları kapsamına 2007 yılından itibaren dâhil edilmiş olup uygulama içerisinde halen devam etmektedir $(1,20,28)$. 


\section{Türkiye’de Su Ürünleri Sektörünün Gelişimine Dönük Çözüm Önerileri}

\section{Su ürünleri avcılı̆ğ:}

Türkiye'de avcılık yoluyla elde edilen üretimde en önemli tür hamsidir. Aşırı av baskısına bağlı olarak avlanma miktarı yıllara bağlı sürekli değişimler gösteren başta hamsi olmak üzere çaça, sardalya gibi göçmen türlerin stoklarının korunması son derece önemlidir. 2012-2018 yılları arasında filodaki balıç̧ı gemilerinin azaltılması için yapılan uygulama, avlanma sezonu ve av yasakları gibi kontrol ve düzenleme tedbirleri sektör açısından olumlu etkileri olan uygulamalardır. Ayrıca yapay resif uygulaması ile balıkların üreme ve yaşam alanlarına sahip olması sağlanarak stokların korunmasına katkı sağlayıcı aksiyonların üretilmesi de önemlidir. Lakin filodaki mevcut gemilerin motor gücü ve hacimlerin artışı, av araç-gereçlerinin ve teknolojik donanımlarının yükselmesi av baskısı oluşturmaya devam etmektedir. Ülke suları dışında avcılık yapma kapasitesine sahip gemilerin az olması, doğal olarak aynı stoktan yararlanmayı da beraberinde getirmektedir. Ayrıca aynı denizlerde avcılık yaptığımız komşu ülkelerle stokların doğru yönetilmesi açısından sürekli işbirliği içerisinde olmakta son derece önemlidir $(12,23)$. Avlanan ürünlerin karaya çıkarılacağı noktaların tespit edilmesi ve bu noktalara idari binaların tesis edilmesi, gerekli kontrol ve kayıt işlemlerinin yapılması açısından önemli konulardandır (23). Sektör açısından güncel ihtiyaçlara cevap verecek şekilde 22.11.2019 tarihinde Resmi Gazete' de yayımlanarak yürürlüğe giren Su ürünleri Kanunu ile birçok açıdan sektöre önemli katkılar sağlayacaktır. Kaçak avcılığın önlenmesi, caydırıcılığı, üreticilerin ve balık stokların korunması, teşvik hususları gibi birçok konuda güncel ihtiyaçlara cevap verecek ikincil mevzuatlarda yapılacak değişikliklerde balıkçılık yönetimi açısından son derece önem arz etmektedir $(19,23)$.

\section{Su ürünleri yetiştiriciliği:}

Yetiştiricilik faaliyetleri devamlı bir artış eğilimi göstermesine rağmen, yetiştiriciliğe uygun alanlar giderek azalmaktadır. Ülkemizde mevcut yüzey su kaynakları, aynı zamanda içme suyu ve/veya sulama suyu olarak kullanılmaktadır. Ayrıca enerji üretim amacıyla su kaynakları üzerinde kurulan hidroelektrik santraller(HES), başta turizm amaçlı kullanım ve diğer başka sektörlerinde su kaynakları üzerinde geliştirdikleri ekonomik değerler söz konusudur. Bu durum su ürünleri yetiştiricilik tesislerinin gelişimine veya yeni tesis kurulumuna olumsuz etki yapmaktadır $(8,23)$. Yetiştiricilik maliyeti açısından en önemli iki konu vardır. Bunlar yem ve yumurta/yavrudur. Yem ham maddesi konusunda dışarıya bağımlılık söz konusudur. Üretim potansiyelindeki değişiklikler, pazarlama ağı ve alanlarında oluşan dalgalanmalara bağlı olarak tüm dünyada hammadde ve yem fiyatları yüksek seyretmektedir. Dünya genelinde artış eğilimi gösteren yetiştiricilik üretimi nedeniyle balık yem fiyatlarının ilerleyen yıllarda da yüksek olacağı düşünülmektedir. Yetiştiricilik açısından bu durum değerlendirildiğinde, dışa bağımlılığın söz konusu olması ve yem fiyatların yüksek seyretmesi, üretim maliyetlerinin de artmasına neden olmaktadır $(12,23)$.

Ülkemizde mevcut bulunan su ürünleri yetiştiricilik tesislerinin birçoğu y1llık 50 ton'dan daha düşük kapasiteyle üretim yapan tesislerdir. Doğal olarak, küçük ölçekli üretim yapan bu grubun yeni teknoloji, yeni üretim teknikleri ve yeni nesil pazarlama yöntemleriyle uyum sorunu yaşamakta ve rekabet açısından dezavantajlı konuma düşmelerine neden olmaktadır (23). Denizlerde kurulan yetiştiricilik tesislerinde, yemlerin depolanması, çalışanlar için sosyal yaşam alanı, su içindeki kafeslere yem sevki için araç-gereçler, hasat edilen ürünün karaya çıarılması gibi yetiştiricilik faaliyetlerin gerçekleştirilmesi için karaya çıkış noktalarında kullanımlarında olması gereken kıyı alanlarına ihtiyaç söz konusudur. Bu ihtiyacın oluşturduğu alanların kullanımında zaman zaman çevre örgütleri ve turizm işletmecileri ile yaşanan olumsuz süreçler, mevcut tesislerin faaliyetlerini etkilediği gibi yeni kurulması düşünülen tesisler açısından veya mevcut yatırımların büyütülmesi hususunda negatif baskı oluşturmaktadır $(9,23)$. Yetiştiricilik yoluyla elde edilen su ürünlerine karşı kamuoyunda ve tüketicilerde oluşturulan yetiştiricilik ürünlerinin sağlıksız olduğu gibi yanlış algılar sebebiyle oluşan şüphe, yetiştiricilik ürünlerinin satışını etkilemektedir. Doğal yaşam koşullarına uyumlu yetiştiricilik yapıldığının ve çevre kirliliği oluşturulmadığının belirtilmesi kadar besleme ve yetiştirme koşullarının sağlık açısından herhangi bir olumsuzluk içermediği konusunda doğru bilgilendirme ve görünürlük çalışmalarına fazlasıyla ihtiyaç vardır (23). Ülkemizde 1970'li yıllardan beri alabalık yetiştiriciliği ile ilgili 
çeşitli araştırmalar yapılmış olsa da devlet veya özel sektör tarafından yürütülmüş uzun süreli bir ıslah çalışması yoktur. Nitelikli ve sertifikalı yumurta-yavru üretmek ve yetiştirme aşamasındaki önemli miktardaki kayıları azaltmak için ıslah çalışmalarının yapılması son derece önemli bir konudur. Yetiştiricilerin kendi imkânlarıyla gerçekleştirdikleri faaliyetlere destek verilmelidir. Yetiştiricilik tesislerine, hastalıktan ari anaç, yavru ve yumurta temin etme imkânları sağlanmalıdır $(12,23)$. Nitelikli damızlık üreten işletmeler kurulması, bu tesislerin desteklenmesi, denetim ve kontrollerin düzenli yapılması önemli ihtiyaçlardandır. Türkiye'deki yumurta ve yavru ihtiyacının sertifikalı işletmeler tarafından sağlanması, bu konuda ihtisaslaşmış tesislerin teşvik ve desteklemelerle sektörde devamlılık göstermesi, sektörün geleceği açısından mühim hususlardandır. Ayrıca sertifikasyon ve biyo-güvenlik uygulamaları, işletmeler arasındaki yumurta, yavru ve balık nakillerinde uygulanacak kontrol mekanizması gibi konularda sektörün hem uluslararası rekabetini arttıracak hem de mevcut kaynakların maksimum verimle kullanımına imkân sağlayacak konular bütünüdür. Sonuç olarak, biyo-güvenlik, sertifikasyon ve damızlık ıslah çalışmaları konuları bir bütün halinde ele alınarak, değerlendirilmelidir (23).

\section{İşleme-Pazarlama:}

Birçok tarımsal ve hayvansal üründe olduğu gibi su ürünleri sektöründe de üreticiler pazarlama da doğrudan etkili değildir. Balıkçı, pazarlamada komisyonculara bağımlı çalışmaktadır. Su ürünleri sektöründe yaygın görülen uygulama ise şöyledir: av sezonu öncesi balıkçı gemi sahipleri bakım-onarım, ekipman alımı ve diğer masrafları için komisyoncusundan avans alır. Borcuna karşılık olarak da av sezonunda avladıkları ürünleri komisyoncusuna getirir. Avcılığı gerçekleştiren üreticilerin, avladıkları ürünlerin fiyatlarının belirlemesinde rolünün düşük kalması olumsuzlukları beraberinde getirmektedir. Ayrıca tüketim alışkanlığı, av miktarı ve tazelik gibi hususlara bağlı olarak gerçekleşen fiyat dalgalanmaları da üreticileri ekonomik açıdan etkileyen unsurlardır. Avcıllğın fazla olduğu dönemlerde doğrudan satışa sunulan miktarlar dışında kalan üretimin su ürünleri işleme fabrikalarına, çok düşük fiyatlarla verilmesi de üreticinin kazancı adına olumsuzluk meydana getiren önemli hususlardandır (12, 23). Fiyat politikalarının belirlenmesinde ve pazarlama kabiliyetleri açısından önemli rol oynaması gereken üretici birlikleri ile kooperatifleri, su ürünleri sektöründe yer alan komisyonculardan daha etkin olmaması da üretici açısından önemli bir sorundur (23). Su ürünleri sektörünün üretimden işlemeye, ürün değerlendirmesinden pazarlama sürecine kadar, bütün süreçlerin bir arada değerlendirilmesi elzemdir. Çok hassas bir ürün olan su ürünlerin taze tüketim kadar işlenmiş ve doğru muhafaza koşullarının sağlanmış olması da önem arz etmektedir (18).

\section{Tüketim:}

Türkiye'nin su ürünleri tüketimi, Avrupa Birliği ülkeleri ve dünya geneli ortalamasıyla karşılaştırdığımıza ilişkin bilgiler Tablo-19'da verilmiştir $(10,26)$.

Tablo 19: Bazı ülkelerde kişi başına düşen su ürünleri tüketim ortalaması $(\mathrm{kg})$

Table 19: Average per capita consumption of fish and fishery products in some countries $(\mathrm{kg})$

\begin{tabular}{lc}
\hline Ülkeler & Tüketim Miktarı (kg) \\
\hline İzlanda & 90,7 \\
Maldivler & 90,4 \\
Hong Kong & 70,8 \\
Malezya & 57,6 \\
İspanya & 40 \\
Yunanistan & 23,1 \\
Fas & 28 \\
Misir & 11,2 \\
Tunus & 9,3 \\
Dünya & 19,2 \\
Avrupa Birliği & 24 \\
Türkiye & 7,6 \\
\hline
\end{tabular}

Kaynak: TUDAV 2017, Demirel ve Hattrl 2020 
Tablo incelendiğinde Türkiye'de ortalama tüketim miktarının AB ülkelerine göre düşük olduğu görülmektedir. $\mathrm{Bu}$ durumu sadece tüketim alışkanlıkları kapsamında değerlendirmek yeterli olmayabilir. Üretilen su ürünlerinin miktar, tür ve bunların fiyatları, tüketicinin alım gücü gibi başka faktörlerde rol almaktadır. Av sezonunda fiyatlar genelde düşmekte, avcılık azaldığında ise ani yükselmeler görülmektedir. Doğal olarak bu durum balık tüketimini olumsuz etkilemektedir. Tüketim miktarını arttıracak çalışmaların yetersiz olması da tüketim ortalamasını düşürmektedir. Y1l boyunca tüketimin sağlanması için işlenmiş ve hazır tüketime sunulan ürün çeşitliliğinin sağlanması, yetiştiricilik yoluyla üretilen su ürünlerine yönelimin arttırılması başta olmak üzere mevsimsel ve taze tüketim alışkanlıklarının dışına çıkılması için tüketimin teşvik edileceği yayın ve tanıtımların yapılması çok elzemdir $(23,30)$.

\section{Su ürünleri kaynakları ve çevre:}

Nüfus artışı, teknolojik gelişim ve küreselleşme politikalarına bağlı olarak ortaya çıkan gereksinimlerin tür ve çeşitliliğin artması, sınırlı doğal kaynakların daha fazla kullanımına neden olmakta ve kaynakların yıpranması, kirlenmesi gibi sonuçları da beraberinde getirmektedir. Su, insan ve diğer canlıların yaşamlarını devam ettirebilmeleri için vazgeçilmez olan dünyadaki en önemli doğal kaynaktır. Bu kaynakların başta endüstriyel ve evsel kökenli kirlilik olmak üzere karşı karşıya kaldığı tehditlerin tespiti ve alınacak tedbirlerin belirlenmesi ve uygulanması, sucul yaşamın korunması kadar dünyanın geleceği açısından da son derece önem arz eden konulardandır. İklim değişikliği, küresel 1sınma gibi kısa vadede kontrol edilmesi güç hususlar da su kaynaklarına ve sucul yaşama olumsuz etkisi bulunmaktadır (23). Ekolojik dengenin bozulmasına yol açan sebepler, sucul yaşamda ekonomik olarak değerli türlerin kaybolmasına ve ekonomik olmayan türlerinde çoğalması sonucunu ortaya çıkarmaktadır. Ayrıca çeşitli yollarla avcılık ve yetiştiricilik yapılan sahalara ulaşan istilacı türler de ekonomik kayıplar oluşturan önemli sorunlardır. Türkiye açısından başta Akdeniz de görülen balon balığı, aslan balığı ve köpek balığı gibi türler, su ürünleri üretimine olumsuz etki yapmaktadır $(12,23)$. Denizlerdeki su ürünleri stokları, kıyıdaş ülkeler arasında paylaşılmaktadır. Stokların yönetimi konusu ülkelerin tek başlarına karar vererek hareket edecekleri bir alan değildir. Sürdürülebilirlik ve üretim artışının sağlanması için sucul yaşamın kıyıdaş ülkelerin ortak hareket edeceği işbirlikleri ile korunması, aşırı ve yasadışı avcılığın önlenmesi ve atık yönetimi gibi konularında uyumlu hareket etmeyi gerektirmektedir (23). İç sularda çevresel yönetim planlarının oluşturulması, enerji ve sulama amaçlı kullanımın doğru planlanması, su kirliliğinin önlenmesi ve sucul yaşamın korunması adına düzenleyici, denetleyici ve caydırıcı yasal tedbirlerin uygulanması önemlidir. Ayrıca Tarım ve Orman Bakanlığı tarafından iç sularda yetiştiriciliğin geliştirilmesi ve kaynakların korunması adına uygulanan, balıklandırma çalışmaları da iç suların geleceği adına önemli faaliyetlerdendir $(18,23)$.

\section{Yeni pazar imkânları :}

Başta Avrupa Birliği (AB) üye ülkeleri olmak üzere, komşu ülke pazarları potansiyelinden yararlanarak ikili ve bölgesel ticari antlaşmalar vesilesiyle dış pazarların geliştirilmesi sektörün gelişimi açısından son derece mühim bir konudur. Zira AB'ye ihraç edilmekte olan en önemli hayvansal ürün su ürünleridir. Sektörün ticari potansiyelinin gelişmesi açısından üretim kadar yeni pazar alanlarının oluşturulması da çok elzemdir.

\section{Sonuç}

Su ürünleri sektörü, Türkiye'nin hayvancılık başlığı altında sıralanan alt sektörleri içerisinde son dönemde ihracat rakamlarının artışı ile birlikte parlayan ve doğal ekosistem içerisinde, insanlık için de vazgeçilmez bir sektörü haline gelmektedir. Bölgesel farklılıkların tüketim tercihleri ve miktarı konusunda değişiklikler olmuş olsa da, en önemli omega-3 kaynağı olması, yüksek protein ihtiva etmesi sebebiyle beslenme açısından da son derece önemli bir yere sahiptir. Avcılık ve yetiştiricilik yoluyla üretim yapılan bu sektörün, teknolojik gelişime açık, sürdürülebilir yöntemlerle, doğanın da korunma önceliğinde olduğu düzenleme ve denetlemelerle Türkiye için önemli kazanımları 
olan ekonomik bir faaliyet olduğu rahatlıkla ifade edilebilir. Ayrıca üç tarafı denizlerle çevrili, birçok yöresinde doğal su kaynakları barındıran ülkemizin, tabi koşullar altında sahip olduğu firsatların yerinde ve kararında değerlendirilmesi son derece mühimdir.

Sektör paydaşları tarafından mavi büyüme olarak ifade edilen su ürünleri üretiminin ve ekonomik değer artışının gerçekleşebilmesi, üretim kadar kişi başına ortalama tüketim miktarının da arttığı durumda tam olarak gerçekleşir. Tüketimin özendirilmesi kadar alternatif işlenmiş ürünlerin geliştirilmesi, kolay tüketim imkânı oluşturan gıdaların içeriğinde işlenmiş su ürünlerin yer alması gibi konularında üzerine eğilmek önemlidir. Ekolojik sistem, aşırı av baskısı karşısında ekonomik olmayan türlerin geniş yaşam alanları bulmasına yol açarak, yeni ve başka bir dengenin oluşmasına sebep olmaktadır. Stokların korunması üretim açısından önemli olduğu kadar sucul yaşamın korunması ve çevre konularını da ilgilendirmektedir. Kirlilik, iklim değişikliğinin etkileri, istilacı türler ve yasadışı avcılık gibi durumların oluşturduğu tahribatların tespiti ve tedbirlerinin alınması gerekir.

Su ürünleri üretiminin arttırılması ile birbirini tamamlayan diğer endüstri alanlarının da gelişimini sağlamak da, ekonomik kalkınma açısından önemlidir. Su ürünleri sektörünün büyümesi ile birlikte su ürünlerine bağlı yan sektör ve üretim dallarının da gelişeceği ve hatta gelişmesi gerekliliği dikkate alındığında, sektörde uzun vadeli ve sürdürülebilir bir üretim planlamasının yapılması ve hayata geçirilmesi Türkiye açısından bir zorunluluktur. Su kaynaklarında aşırı üretim kadar önemli bir diğer konun da atıl üretim kapasitesi olduğu unutulmamalıdır. Toplam kapasitesinin çok altında üretim yapılan alanların doğru değerlendirilmesi, Türkiye'de su ürünleri sektörü için bir gerekliliktir. Sektörün taşıdığı potansiyeli, karşılaştığı ve karşılaşabileceği tehditlerin iyi bilinmesi, sektöre yönelik verilerin sürekli güncellenmesi ve yeni hedeflerin ortaya konması ve bu verilerin araştırma ve geliştirme çalışmalarına öncülük etmesi adına önem arz etmektedir.

\section{Çıkar Çatışması Beyanı}

Makalenin yazarları arasında bu derleme çalışması kapsamında herhangi bir kişisel ve finansal çıkar çatışması bulunmamaktadır.

\section{Finansal Kaynak Beyanı}

$\mathrm{Bu}$ çalışma sırasında, yapılan araştırma konusu ile ilgili doğrudan bağlantısı bulunan herhangi bir ilaç, firmasından, tıbbi alet, gereç, ve malzeme sağlayan ve/veya üreten bir firma veya herhangi bir ticari firmadan, çalışmanın değerlendirme surecinde, çalışma ile ilgili verilecek kararı olumsuz etkileyebilecek maddi ve/veya manevi herhangi bir destek alınmamıştır.

\section{Yazar Katkısı Beyanı}

Fikir/kavram: İsmail Şakıma, Mustafa Bahadır Çevrimli

Deney tasarımı: İsmail Şakıma, Mustafa Bahadır Çevrimli

Denetleme/Danışmanlık: Mustafa Bahadır Çevrimli

Veri toplama: İsmail Şakıma, Mustafa Bahadır Çevrimli

Veri analizi ve yorum: İsmail Şakıma, Mustafa Bahadır Çevrimli

Kaynak taraması: İsmail Şakıma, Mustafa Bahadır Çevrimli

Makalenin yazımı: İsmail Şakıma, Mustafa Bahadır Çevrimli

Eleştirel inceleme: Mustafa Bahadır Çevrimli

\section{Etik Onay}

Bu makaledeki sunulan verilerin, bilgilerin ve dokümanların akademik ve etik kurallar çerçevesinde elde edildiği, tüm bilgi, belge, değerlendirme ve sonuçlarının bilimsel etik ve ahlak kurallarına uygun olarak sunulduğuna dair yazarlardan etik beyan alınmıştır. 


\section{Kaynaklar}

1. Arslan MN, Akhan S (2018): Dünyada Su Ürünleri Yetiştiricilik Sigortaları Uygulamaları, JAES, 3(3), 152157.

2. Arıkan MS, Aral Y (2019): Economic analysis of aquaculture enterprises and determination of factors affecting sustainability of the sector in Turkey, Ankara Üniv Vet Fak Derg, 66, 59-66.

3. Atar HH, Kömürlü U (2018): Su Ürünlerinde Teşvik Uygulamalarl, Üçüncü Sektör Sosyal Ekonomi Dergisi, 53(2), 662-677.

4. Aydoğdu Sİ (2015): Elazı̆̆ Yöresi’nde Gökkuşă̆ı Alabalı̆̆ (oncorhynchus mykıss) Yetiştiriciliği yapan Farkl Kapasitedeki İşletmelerin Yapısal, Teknolojik, Verimlilik ve Çalışanlarının Sosyo-ekonomik Analizleri, Firat Üniversitesi Fen Bilimleri Enstitüsü, Doktora Tezi, Elazı̆g.

5. BAKA (2012): Su Ürünleri Sektör Raporu, Batı Akdeniz Kalkınma Ajansı, Isparta.

6. BSGM (2020): Su Ürünleri İstatistikleri Kitabı. Tarım ve Orman Bakanlığı Balıkçılık ve Su Ürünleri Genel Müdürlüğü, Ankara.

7. Birişik N (2019): Küresel ve Ulusal Ölçekte Tarım ve Gıda Politikaları, Tarım-Orman Çalışanları Birliği Sendikas1, Ankara.

8. Çımat A, Duran T (2018): Muğla İli Su Ürünleri Kooperatif İşletmelerinin Karşılaştıkları Temel Sorunlar Ve Çözüm Önerileri, Elektronik Sosyal Bilimler Dergisi, 17(66), 433-453.

9. Demir O (2011): Türkiye Su Ürünleri Yetiştiriciliği ve Yem Sektörüne Genel Bakış - II, ISUBÜ Eğirdir Su Ürünleri Fakültesi Dergisi 7(1), 39-49.

10.Demirel O, Hatırlı SA (202): Türkiye'de Hanehalklarının Balık Tüketim Harcamaları: Logıt Ve Multınomıal Logıt Yaklaşımları, MAKÜ İktisadi ve İdari Bilimler Fakültesi Dergisi, (7), 1022-1045.

11.Doğan K (2018): İstanbul İli Su Ürünleri Kooperatiflerinin Ticari Olanakları Ve Sorunlarının Incelenmesi, Aquat Res. 1(4), 180-191.

12.DPT (2001): Sekizinci Beş Yıllık Kalkınma Planı Su Ürünleri ve Su Ürünleri Sanayii Özel İhtisas Komisyonu Raporu, Devlet Planlama Teşkilat1, Ankara.

13. FAO (2016): The State of World Fisheries and Aquaculture. Erişim: http//:www.fao.org/FAO Home/Fisheries\&Aquaculture. Erişim tarihi:18.05.2021

14.FAO (2018): Dünyada Balıkçılık ve $\mathrm{Su}$ Ürünleri Yetiştiriciliğinin Durumu. Erişim: http://www.fao.org/3/CA0191TR/ca0191tr.pdf. Erişim tarihi: 18.05.2021

15.İO (2018): Glda, Tarım ve Hayvancllı Sektör Raporlarl, Erişim: İmir.http://izto.org.tr/demo_betanix/uploads/cms/yonetim.ieu.edu.tr/6414_1536313627.pdf). Erişim tarihi: 20.04.2020.

16.Karademir M, Arat ME (2014): Su Ürünleri Kooperatiflerinde Karşılaşılan Sorunlar Ve Çözüm Önerileri: Ístanbul İli Örneği, Öneri Dergisi, 11(41), 133-156.

17.Kömürlü U, Atar HH (2019): Su Ürünlerinde Kredi Uygulamalarl, Üçüncü Sektör Sosyal Ekonomi Dergisi, 54(3), 1300-1318.

18.SUYMERBİR (2019): 7. Su Ürünleri Yetiştiriciliği Çalıştayl, Su Ürünleri Yetiştiricileri Üretici Merkez Birliği, Antalya.

19.SUYMERBİR (2020): 8. Su Ürünleri Yetiştiriciliği Çalıştayı, Su Ürünleri Yetiştiricileri Üretici Merkez Birliği, Antalya.

20.Sümer G, Polat Y (2016): Dünyada Tarım Sigortaları Uygulamaları Ve TARSIM, GÜ İktisadi ve İdari Bilimler Fakültesi Dergisi 18(1), 236-263.

21.Oma İEC (2019): Türkiye'de Balık Yetiştiriciliğinde Kullanılan Kalite Sistemlerinin Etkilerinin Balık Sağlı̆̆ Açısından Değerlendirilmesi, İstanbul Üniversitesi Fen Bilimleri Enstitüsü, Yüksek Lisans Tezi, İstanbul.

22.Örnekci GN (2018): Keban Baraj Gölü'ndeki Su Ürünleri Yetiştiricilik Isşletmelerinin 2015 Yılı Yapısal Ve Ekonomik Analizi, Munzur Üniversitesi Fen Bilimleri Enstitüsü, Yüksek Lisans Tezi, Tunceli.

23.TAGEM (2019): Su Ürünleri Sektör Politika Belgesi, Tarım ve Orman Bakanlığı Tarımsal Araştırmalar ve Politikalar Genel Müdürlüğü, Ankara.

24.TOB (2020): Hayvancıllk Desteklemeleri, Erişim: https://www.tarimorman.gov.tr/Konular/TarimsalDestekler/Hayvancilik-Desteklemeleri/Su-Urunleri). Erişim tarihi:05.05.2020. 
25.TRGM (2021): Tarımsal Amaçlı Kooperatiflerin Sayısl, Erişim: https://www.tarimorman.gov.tr/sgb/Belgeler/SagMenuVeriler/TRGM.pdf). Erişim Tarihi:10.02.2021.

26.TUDAV (2017): Türkiye Denizleri Raporu, Erişim: https://tudav.org/wpcontent/uploads/2018/04/TUDAV_2017_Denizler_Raporu_s.pdf). Erişim Tarihi: 10.02.2021.

27. Yazıcı Ö, Atar HH (2017): Türkiye’ de su ürünlerinde Örgütlenme, Ziraat Mühendisliği Dergisi, (364), 60 - 64.

28. Yeşilayer N, Gören HM, Kaymak İE (2013): Mevcut Durum ve Destekleme Politikaları Bakış Açısından, Türkiye ve Avrupa Birliği Su ürünleri Yetiştiriciliğinin Karşılaştırılması, GBAD, (3), 59-75.

29. Yılmaz S, Yılmaz İ (2017): Su Ürünlerinde İzlenebilirliğin Pazarlamadaki Önemi, Nevşehir Bilim ve Teknoloji Dergisi, (6), 233-242.

30. Yüksel F (2017): Su Ürünleri Yetiştiriciliğinde Ürün Destekleme Politikalarının Değerlendirilmesi, Munzur Üniversitesi, Fen Bilimleri Enstitüsü, Yüksek Lisans Tezi, Tunceli. 